\title{
华北克拉通南缘晚中生代花岗质岩浆作用与构造 演化
}

\author{
高昕宇, 赵太平* \\ 中国科学院广州地球化学研究所矿物学与成矿学重点实验室, 广州 510640 \\ *通讯作者, E-mail: tpzhao@gig.ac.cn \\ 收稿日期: 2016-12-13; 接受日期: 2017-06-06; 网络版发表日期: 2017-07-20 \\ 国家重点研发计划项目(编号: 2016YFC0600106)和国家自然科学基金项目(批准号: 41402047、41373046)资助
}

\begin{abstract}
摘要华北克拉通南缘在晚中生代158 112Ma发生大规模的花岗质岩浆活动, 以及同时期的钼-金-银-铅-锌 多金属矿床成矿作用。通过分析这些花岗岩类岩石的元素和同位素地球化学特征以及精确的年代学研究成果, 发现它们的地球化学特征在 $127 \mathrm{Ma}$ 前后有明显差异: 早期(158 128Ma)主要形成I型花岗岩, 以不具有明显的 $\mathrm{Eu}$ 负异常、富集大离子亲石元素和亏损 $\mathrm{Y} 、 \mathrm{Yb}$ 等重稀土元素为特征; 晚期花岗岩(126 112Ma)更富硅和钾, Eu负 异常明显, 具有更高的 $\mathrm{Y} 、 \mathrm{Yb}$ 含量和 $\mathrm{Rb} / \mathrm{Sr}$ 比值, 而 $\mathrm{Sr} 、 \delta \mathrm{Eu} 、 \mathrm{Sr} / \mathrm{Y}$ 比值等明显降低, 主要为 $\mathrm{A}$ 型和高分异 $\mathrm{I}$ 型花岗 岩, Sr、 $\mathrm{Nd}$ 、 Hf 同位素组成相对早期的更亏损, 并伴随少量基性岩浆岩的发育. 两期花岗岩均主要形成于以华 北克拉通结晶基底为主的古老地壳物质的部分熔融, 并有幔源岩浆的参与; 由早到晚, 幔源组分显著增多. 这些 特征反映了地壳厚度有减薄的趋势, 并在 $127 \mathrm{Ma}$ 发生明显的减薄, 证明 $127 \mathrm{Ma}$ 是华北克拉通南缘中生代构造体 制转折的关键时期; 该时期的构造演化及岩浆作用, 与太平洋板块俯冲引起的幔源岩浆底侵从而引发的强烈壳 幔相互作用有关, 并促使岩石圈强烈伸展减薄.
\end{abstract}

关键词华北克拉通南缘, 晚中生代, 花岗岩, 物质来源, 构造演化

\section{1 引言}

大量地质、地球物理和地球化学资料表明, 华 北克拉通的太古宙岩石圈根 $(>200 \mathrm{~km})$ 在中-新生代时 期被强烈破坏和减薄, 幅度可能大于 $80 \sim 120 \mathrm{~km}$ (Peng 等, 1986; Basu等, 1991; Menzies等, 1993; Fan等, 2000; Kusky等, 2007; Yang等, 2008a; 朱日祥等, 2011). 构 造体制从三叠纪时期的挤压环境向晚侏罗世-白严纪
的伸展环境转变, 发育大量的伸展构造(如变质核杂 岩)(Zhang和Zheng, 1999; Davis等, 2002; Liu等, 2005)、 断陷盆地(Ritts等, 2001; Ren等, 2002)、大面积的岩浆 侵位和火山喷发以及 $\mathrm{Au}-\mathrm{Ag}-\mathrm{Mo}$ 多金属矿床的大规模 成矿(陈衍景等, 1998; Mao等, 2011; Li等, 2012a; Zhai和 Santosh, 2013; Goldfarb和Santosh, 2014). 华北克拉通 南缘在这一时期也发育了大规模的Mo-Au-Ag-Pb-Zn 多金属矿床的成矿作用(Mao等, 2011; Deng 等, 2014;

中文引用格式: 高听宇, 赵太平. 2017. 华北克拉通南缘晚中生代花岗质岩浆作用与构造演化. 中国科学: 地球科学, 47: 1309-1328, doi: 10.1360/N072016-00236

英文引用格式： Gao X Y, Zhao T P. 2017. Late Mesozoic magmatism and tectonic evolution in the Southern margin of the North China craton. Science China Earth Sciences, 60: 1959-1975, doi: 10.1007/s11430-016-9069-0 
Bao等, 2017)和以花岗岩为主的岩浆侵位事件(Mao等, 2010; Gao等, 2014a, 2014b; Wang X X等, 2015; Bao等, 2017)(图1c).

这一时期的岩浆作用记录了晚中生代华北南缘 构造演化及华北克拉通岩石圈减薄的地质过程. 因此, 对它们的时空演化规律、岩石成因和岩浆源区等的 相关研究, 能有效反演华北克拉通南缘岩石圈减薄的 时空特点和机制, 并为探讨花岗岩与多金属矿床的成 因关系提供线索. 正因此, 华北南缘中生代花岗岩的 成因研究一直受到众多学者的关注.

近十年来, 对华北克拉通南缘晚中生代的岩浆作 用, 尤其是与成矿作用有关的花岗岩的成因和物质 源区的研究已经取得长足进展, 很多学者围绕年代学 和地球化学等方面进行了大量工作, 积累了丰富的资 料(Mao等, 2010; 高昕宇等, 2010, 2012; Ding等, 2011; 王晓霞等, 2011; Li N等, 2012; Zhao等, 2012; Gao等, 2014a, 2014b; Wang X X等, 2015; Bao等, 2017), 但在物 质来源、形成的地球动力学背景及与造山带演化之 间的关系等方面仍存在争议. 由于华北克拉通南缘大 规模钼多金属成矿作用主要发生在晚中生代, 因此晚 中生代大规模成岩-成矿事件与秦岭-大别造山带演化 过程、扬子与华北克拉通的碰撞拼合及中国东部中 生代太平洋板块俯冲引发的构造转折-岩石圈减薄等 重要地球动力学过程的关系等, 也是当前备受关注的 重要科学问题.

为此, 本文在系统总结华北克拉通南缘晚中生代 花岗岩的岩石学、同位素年代学、元素和同位素地 球化学等方面资料的基础上, 通过岩浆岩的时空演变 和岩石组合特征的研究, 来探讨源区物质来源及其形 成的地球动力学机制.

\section{2 地质背景}

华北克拉通南缘, 北以三门峡-鲁山断裂带为界与 华北克拉通相连, 南以洛南-奕川断裂带为界与秦岭造 山带相接, 是华北克拉通的重要组成部分(任纪舜等, 1990). 自晚二叠至早三叠世, 华北和扬子两大板块陆 陆碰撞拼合(Wu和Zheng, 2013), 华北克拉通南缘卷入 秦岭造山带的构造运动中, 直至晚三叠世( 235Ma) 完 全闭合, 华北克拉通南缘也成为了秦岭造山带岩石圈 的重要组成部分(图1b). 它处于稳定克拉通到活动造
山带的过渡区, 形成与演化同整个秦岭构造带息息相 关, 具有秦岭-大别造山带的地质构造演化特征, 但又 与华北克拉通地质构造发展密切相关. 华北克拉通南 缘地壳物质组成的突出特点是与华北克拉通一样具 有结晶基底和盖层的双层结构; 区域性构造以近东西 向为主, 叠加北东-北北东向构造.

华北克拉通南缘结晶基底由古元古代-新太古代 (2.84 2.26Ga) 太华群组成. 太华群是以斜长角闪岩、 TTG片麻岩、混合岩和变质表壳岩为主的一套中高级 区域变质岩, 其变质程度普遍达角闪岩相, 局部达麻 粒岩相(Kröner等, 1988; Wan等, 2006; Xu X S等, 2009; Huang等, 2010, 2012). 不整合覆盖在太华群之上的沉 积盖层是古元古代熊耳群火山岩(1.80 1.75Ga)(Zhao $\mathrm{T}$ P等, 2004). 熊耳群火山岩在区内分布面积大于 $60000 \mathrm{~km}^{2}$, 局部厚度可达 $7600 \mathrm{~m}$, 岩性以高钾富铁的 中基性-中酸性熔岩为主, 局部发育火山碎屑岩层和 沉积岩夹层 $(<5 \%)$ (Zhao T P 等, 2004). 盖层岩系除熊耳 群火山岩外, 还包括中元古代官道口群和汝阳群滨海 相陆源碎屑岩-碳酸盐岩建造、新元古代栾川群和洛 峪群浅海相碎屑岩-碳酸盐岩和碱性火山岩建造, 以 及零星出露的震旦系、寒武系、白严系和大面积的 新生代地层.

中生代时期华北克拉通南缘岩浆作用集中在二叠 纪和晚侏罗至早白严世. 其中二叠纪岩浆岩主要岩性 为石英二长岩、石英闪长岩、二长花岗岩和正长花 岗岩, 呈岩脉或岩株状产出, 仅在华北克拉通南缘的西 部小秦岭和熊耳山地区有少量发育, 如小秦岭老牛山 杂岩体中的二叠纪侵入体 (228 214Ma, Ding等, 2011; 齐秋菊等, 2012)、瓮峪花岗岩(205Ma, Hu等, 2012)和 熊耳山寨凹花岗岩脉(217.7Ma, 李厚民等, 2012). 晚侏 罗至早白严世花岗岩在华北克拉通南缘广泛发育(图 $1 \mathrm{c}$ 和2), 以地表出露面积广大、多期次侵入的复式花 岗岩基为主, 岩性多为斑状、似斑状黑云二长花岗岩 和黑云母花岗岩、正长花岗岩, 侵位时间持续数个百 万年到数十个百万年. 与此同时, 也发育大量的与成 矿作用有关花岗斑岩体, 斑岩体规模小, 出露面积小 于 $1 \mathrm{~km}^{2}$, 其侵位与定位主要受断裂控制, 岩体直接产 于断裂带中, 沿断裂带成群成带分布.

华北克拉通南缘也是我国著名的成矿带, 发育大 规模的Mo-Au-Ag-Pb-Zn 多金属成矿作用, 在空间上矿 床多沿构造-岩浆带展布, 与深大断裂带方向大体一致, 

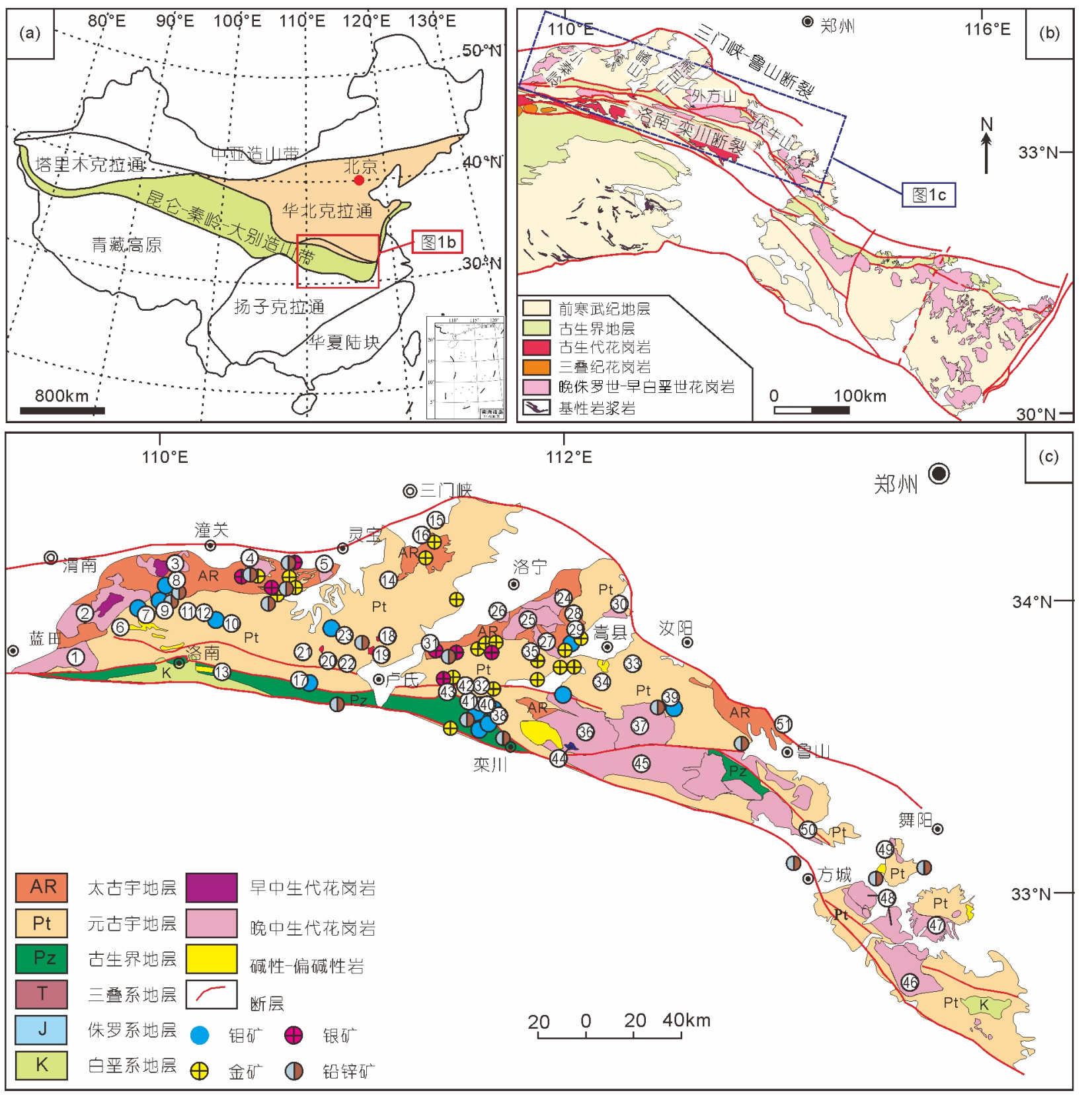

图 1 华北克拉通南缘晚中生代花岗岩和矿产分布图

(a) 中国地质简图; (b) 秦岭造山带大地构造简图(图b据张国伟等(1996), 有修改); (c) 华北克拉通南缘晚中生代花岗岩和矿产分布图(岩体编 号同网络版附表 1 4, http://earthcn.scichina.com)

走向EW-NWW, 控矿断裂以NW 向的张性断裂系统为 主(图1c), 自西向东依次分为小秦岭金(钼)矿集区、 崤山金(银)矿集区、熊耳山锄、金、银-铅-锌矿集区 及外方山钿、铅-锌矿集区(图1c), 发育大规模斑岩型 钼矿, 爆破角砾岩型、构造蚀变岩型和石英脉型金矿, 热液脉状银铅锌矿床. 本区成矿作用主要集中于中生
代时期, 其中早中生代识别出的成矿事件较少, 典型 的有小秦岭地区大湖石英脉型钼-金矿床(218 232Ma, 李厚民等, 2007; 李诺等, 2008) 和黄龙铺碳酸盐脉型 钼矿床(216 222Ma, 黄典豪等, 2009; 许成等, 2009)等. 晚中生代主要成矿期与大规模的岩浆作用近同期,集 中于晚侏罗到早白严世, 且多与同期花岗岩, 尤其是 


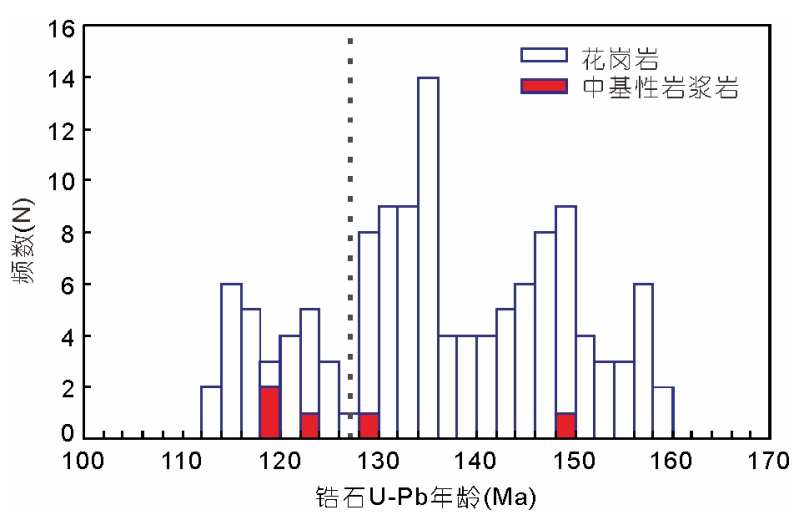

图 2 华北克拉通南缘晚中生代岩浆岩锆石 U-Pb年龄 分布图

数据来源同网络版附表 1

小斑岩体相伴生产出, 二者有密切的成因关系(Mao等, 2008; Deng等, 2014; Bao等, 2017).

\section{3 年代学格架}

近十年来, 国内外学者对华北克拉通南缘晚中生 代花岗岩做过大量高精度的同位素年代学工作, 作者 将这些年龄数据总结于网络版附表 1 中.

年代学结果表明, 晚中生代岩浆活动形成于 158 112Ma, 岩浆作用持续近50Ma, 在约128 126Ma 存在短暂的间歇期(图2, 网络版附表1). 近年来也识 别出零星分布的与花岗岩和多金属矿床同期的中基 性岩浆岩, 其锆石U-Pb年龄为 $148 \sim 117 \mathrm{Ma}$, 主要集中在 129 117Ma(谢桂青等, 2007; 包志伟等, 2009; 赵海杰 等, 2010b; Gao等, 2014a).

根据岩浆作用规模, 花岗岩的形成时间可分为两 个阶段, 早期阶段为晚侏罗-早白严世(158 128Ma), 代 表了这一大规模岩浆活动的主体阶段, 有 14 个大型多 期侵位形成的复式花岗岩基和 32 个小岩体组成, 在小 秦岭、崤山、熊耳山、外方山和伏牛山地区均有出 露(图1c, 网络版附表1).

多期次侵入体构成的复式花岗岩基自西向东有小 秦岭地区的蓝田(154 133Ma)、老牛山(152 145Ma)、 华山 (143 132Ma)、文峪 (138 131Ma) 和娘娘山岩 体 (142 133Ma), 熊耳山地区的花山 (132Ma)、蒿坪 (130 129Ma)、五丈山岩体(156Ma), 外方山地区的合 峪(148 134Ma)、太山庙(126 113Ma)、石宝沟岩体 (157 145Ma) 以及伏牛山地区的黄山(133Ma)、祖师
顶(132Ma)和张士英岩体(124 104Ma)等(网络版附表 1). 这些岩体的形态呈不规则状, 无变形变质特征, 主 要岩石类型为似斑状、含斑或无斑二长花岗岩和正 长花岗岩, 主要矿物组成为钾长石、斜长石、石英、 黑云母、角闪石等, 副矿物为磁铁矿、榍石、磷灰石 和锆石等. 已有的年龄数据显示, 复式花岗岩基的侵 位时间多持续数个百万年到数十个百万年, 且随时间 由早到晚, 不同期次侵入体的岩石结构构造和岩石 类型呈有规律的变化, 如斑晶逐渐变小直至消失, 粗 粒逐渐向中细粒演化等. 较典型的岩基如外方山地 区的合峪花岗岩基形成时间持续14Ma, 随着形成时 间由老到新, 各期次侵入体主要岩石类型由大斑状 中粗粒黑云母二长花岗岩逐渐向无斑细粒黑云母二 长花岗岩和细粒正长花岗岩演变, 斑晶和基质粒度 均明显减小, 钾长石含量逐渐增加, 由二长花岗岩向 正长花岗岩演化.

小岩体多为花岗斑岩或钾长花岗斑岩, 如金堆 城、黄龙铺、夜长坪、雷门沟和南泥湖等, 出露面积 均小于 $1 \mathrm{~km}^{2}$, 岩体具有典型的斑状结构, 侵位与定位 主要受断裂控制, 甚至岩体直接产于断裂带中. 这些 斑岩体多与区域矿化, 尤其是Mo矿化有成因关系, 钿 矿化发育在岩体内部、接触带或围岩中.

基性岩浆作用在这一阶段极少发育, 目前仅在小 秦岭地区黄龙铺岩体和橸川地区西沟铅锌矿区发现有 限几条辉绿岩和辉长岩脉, 分别形成于 129 和 $148 \mathrm{Ma}$ (包 志伟等, 2009; 赵海杰等, 2010b).

晚期阶段的岩浆作用集中在早白严世晚期 (126 112Ma), 规模较早期小, 由太山庙、伏牛山和角 子山三个复式岩基以及东沟、张士英和尚古寺三个 小斑岩体组成, 分布于华北南缘东部的外方山和伏牛 山地区, 岩性主要为正长花岗岩、二长花岗岩和石英 正长岩等(图1c, 网络版附表1).

这一时期中基性岩浆作用规模较早期大, 包括外 方山地区天桥沟闪长岩(122Ma)(Gao等, 2014a)、宝丰 盆地大营组基性火山岩(117Ma)(谢桂青等, 2007)和侵 入于伏牛山花岗岩基中的煌斑岩墙(116Ma)(高昕宇, 2012). 华北克拉通南缘晚中生代岩浆作用的年龄数 据反应出整个区域的岩浆作用时间总体上表现出由 西向东逐渐年轻的特征.

华北克拉通南缘晚中生代的构造活动及广泛发 育的花岗质岩体对成矿作用也产生了重要影响. 在空 
间上,多金属矿床与岩体紧密的分布在同期侵入岩附 近. 近年来对成矿年代学研究表明, 研究区内晚中生代 钿-金成矿作用均集中于 $157 \sim 115 \mathrm{Ma}$ (王义天等, 2001; Wang等, 2002; Mao等, 2008; 焦建刚等, 2009; 李诺等, 2009; 姚军明等, 2009; 高亚龙等, 2010; 黄凡等, 2010; 刘军等, 2011; Li N等, 2012; Li等, 2012a, 2012b; Tang K F等, 2013; Deng等, 2014; 唐克非, 2014), 显示出华北南 缘晚中生代成矿大爆发和岩浆作用广泛发育在时间 和空间上均高度吻合.

除华北克拉通南缘外, 这一时期的岩浆作用在整 个中国东部均有广泛分布. 在邻区的大别-苏鲁造山 带发育大量晚侏罗-早白严世岩浆岩, 同位素年龄集中 在111 161Ma(Xue等, 1997; Hacker等, 1998; Zhao Z F 等, 2004; Yang等, 2005; Wu等, 2005; Xie等, 2006; Wang 等, 2007; Xu等, 2007; Zhao D P等, 2007). 其中晚侏罗 世的花岗岩出露较少, 主要位于苏鲁造山带东部, 岩 性为花岗闪长岩、二长花岗岩和含石榴子石淡色花 岗岩, 锆石 $U-\mathrm{Pb}$ 年龄为 $142 \sim 161 \mathrm{Ma}$ (胡芳芳等, 2004; 郭 敬辉等, 2005). 大别-苏鲁造山带出露面积最广的是早 白严世花岗岩, 同位素年龄集中于111 143Ma, 峰期在 125 130Ma(赵子福和郑永飞, 2009); 从侵位时间上也 可分为早晚两期, 早期岩浆岩侵位时间在 $130 \mathrm{Ma}$ 以前, 存在不同程度的构造变形(马昌前等, 2003; Wang等, 2007; Xu等, 2007), 晚期岩浆岩侵位时间在130 111Ma, 以缺乏构造变形为特征(Jahn等, 1999; Zhao ZF等, 2004; Xie等, 2006; Xu等, 2007; Zhao Z F 等, 2007).

辽东半岛进入中生代后也发生了强烈的岩浆活 动, 区内分布有约 $30000 \mathrm{~km}^{2}$ 的中生代花岗岩, 岩石类型 多样, 几乎包括了所有类型的侵入岩, 组成规模不等的 岩体. 辽东半岛中生代花岗质岩浆作用可划分为三个 阶段: 三叠纪(233 212Ma)、侏罗纪(180 156Ma)和早 白严世(131 113Ma); 三叠纪花岗岩出露较少, 主要以 侏罗纪和早白严世花岗质岩石为主(吴福元等, 2005; Yang等, 2008b). 侏罗纪时期辽东半岛的岩浆活动主要 以花岗岩为主, 缺少基性侵入岩(吴福元等, 2007; Xu Y G等, 2009). 早白严世花岗岩(131 113Ma)的岩石类 型复杂, 不仅发育有大面积的I型花岗岩, 还出露大量 $\mathrm{A}$ 型花岗岩及碱性岩和基性岩脉, 且以 $\mathrm{A}$ 型花岗岩占 主体, 并伴随大规模金矿床产出(Yang等, 2006, 2008b).

上述资料表明, 华北克拉通南缘晚侏罗到早白严 世花岗质岩浆活动两个阶段的年龄和苏鲁-大别地区
及辽东半岛同期花岗岩的形成时代基本一致, 这一时 期的地质事件在华北克拉通东部乃至中国东部不同 地区均有相同的地质响应.

\section{4 地球化学特征}

\section{1 元素地球化学}

华北克拉通南缘晚中生代花岗岩具有较大的成 分变化范围(图3 7), 碱含量较高, 在 $\mathrm{K}_{2} \mathrm{O}-\mathrm{SiO}_{2}$ 图解上 主要分布在高钾钻碱性和钾玄岩系列区域内(图3), 为 准铝质到过铝质(图4). 稀土模式表现出明显的轻稀土 富集(图6a和b). 在Harker图解上, 所有样品均与 $\mathrm{SiO}_{2}$ 呈 连续负相关演化趋势(图5a f), 表明这些花岗岩是由 地球化学组成不均一的源区物质部分熔融所形成.

区域内晚中生代花岗质岩浆活动从地球化学特 征上, 早晚两期岩浆作用有明显区别:

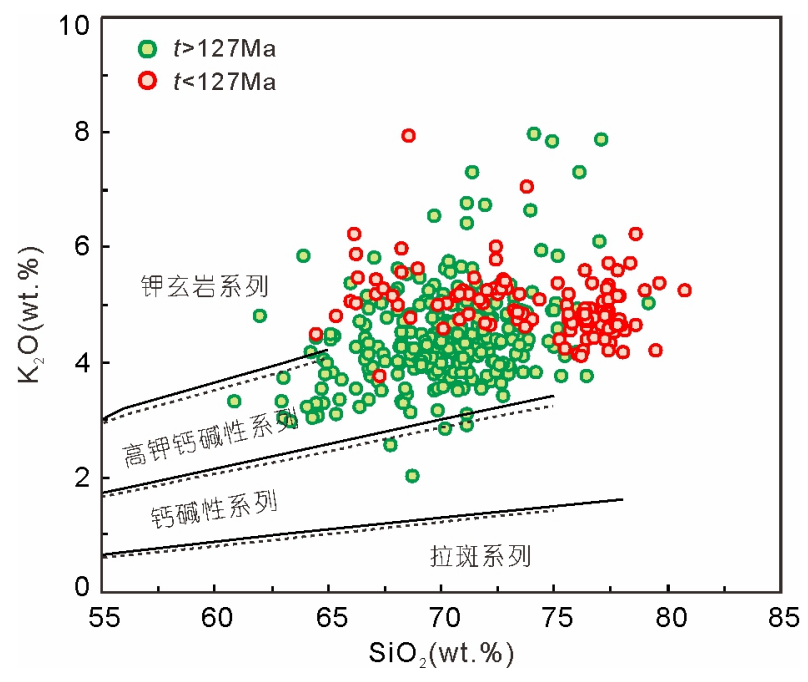

图 3 华北克拉通南缘晚中生代花岗岩 $\mathrm{K}_{2} \mathrm{O}-\mathrm{SiO}_{2}$ 图

分界线据: Peccerillo和 Taylor(1976)、Middlemost(1985); 数据来 源：叶会寿等(2008)、周红升等(2008)、周珂(2008)、朱赖民等 (2008)、包志伟等(2009)、戴宝章等(2009)、郭波等(2009)、焦建 刚等(2009)、倪智勇(2009)、向君峰(2009)、许道学(2009)、姚军 明等(2009)、高昕宇等 $(2010,2012) 、$ 李创举和包志伟(2010)、赵海 杰等(2010a, 2010b)、王晓霞等(2011)、Hu等(2012)、Yang(2012)、 Zhao等(2012)、齐秋菊等(2012)、肖娥等(2012)、肖鸿等(2012)、 Yang等(2013)、Zhu等(2013)、柯昌辉等(2013)、李否等(2013)、李 铁刚等(2013)、Bao等(2014)、Gao等(2014a, 2014b)、Yang Z F等 (2014)、李正远等(2014)、卢仁等(2014)、齐玥(2014)、Wang C M 等(2015)、段友强等(2015)、赖相濡(2015)、梁涛和卢仁(2015)、 张灯堂等(2015)、张兴康等(2015)、王赛等(2016) 


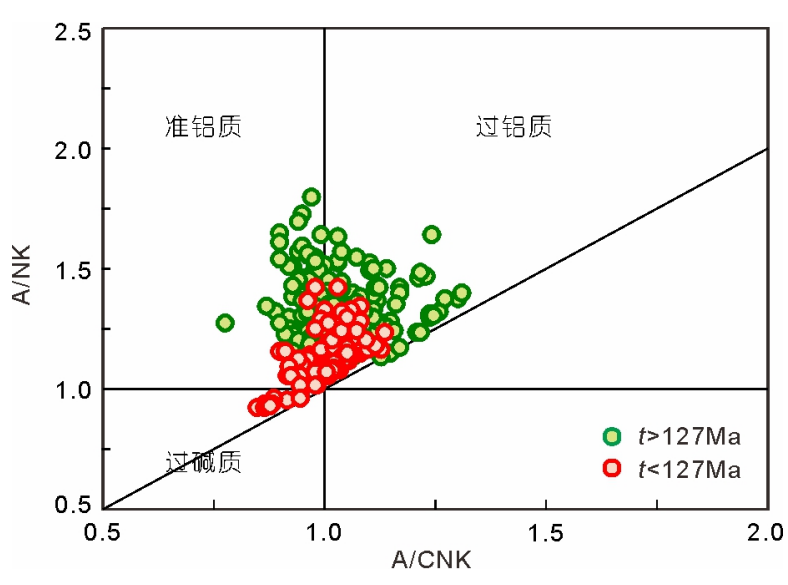

图 4 华北克拉通南缘晚中生代花岗岩A/NK-A/CNK图 分界线据: Maniar和Piccoli(1989); 数据来源同图3

早期阶段(158 128Ma) 岩体 $\mathrm{SiO}_{2}=60.84 \sim 79.13 \%$, $\mathrm{Na}_{2} \mathrm{O}+\mathrm{K}_{2} \mathrm{O}=4.35 \sim 10.5 \%$ (图3). 稀土元素分馏较大, 轻 稀土富集, 重稀土亏损, 配分曲线呈明显右倾型, 具有 弱 $\mathrm{Eu}$ 负异常或不具有 $\mathrm{Eu}$ 负异常 $(\delta \mathrm{Eu}=0.66 \sim 1.49$ )(图6a), 富集大离子亲石元素 $(K 、 R b 、 S r 、 B a), Y$ 和 $Y b$ 等重 稀土元素含量较低(图 $7 \mathrm{a} \sim \mathrm{f})$.

晚期阶段 (126 112Ma) 岩体较早期岩体 有更高的 $\mathrm{SiO}_{2}$ 和碱含量 $\left(\mathrm{SiO}_{2}=64.45 \sim 80.78 \%\right.$, $\mathrm{Na}_{2} \mathrm{O}+\mathrm{K}_{2} \mathrm{O}=7.05 \sim 14.36 \%$ )(图3), 更低的 $\mathrm{A} / \mathrm{NK}$ 和 $\mathrm{A} / \mathrm{CNK}$ 值(图4), 表现出强烈富硅、富钾的特征, 在 $\mathrm{K}_{2} \mathrm{O}-\mathrm{SiO}_{2}$ 图解上主要分布于钾玄岩系列(图3). 轻稀土较富集, 重稀土弱亏损, Eu负异常明显(0.09 0.77)(图6b), Sr和 $\mathrm{Ba}$ 元素含量相对较低. 如图7所示, 元素含量或比值在 $\sim 127 \mathrm{Ma}$ 前后, 或突然升高或突然降低, 发生了非常明 显且迅速的变化, 晚期岩体具有更高的 $Y 、 Y b$ 含量和 $\mathrm{Rb} / \mathrm{Sr}$ 比值, 而 $\mathrm{Sr}$ 、 $\delta \mathrm{Eu} 、 \mathrm{Sr} / \mathrm{Y}$ 比值均显示出明显降低.

\section{2 同位素地球化学}

为示踪华北克拉通南缘早白严世花岗岩的源区 特征, 本文统计了华北克拉通南缘晚中生代花岗岩的 $\mathrm{Sr} 、 \mathrm{Nd} 、 \mathrm{Hf} 、 \mathrm{~Pb}$ 同位素组成(网络版附表2, 图8 10). 华北克拉通南缘各地区中生代花岗岩具有相似的初 始 $\left({ }^{87} \mathrm{Sr} /{ }^{86} \mathrm{Sr}\right)$ 比值, 介于 $0.7050 \sim 0.7236$, 具有中等的初 始 $\mathrm{Sr}$ 同位素比值. 它们具有较低的放射成因 $\mathrm{Pb}$ 同位素 组成, 其中 $\left({ }^{206} \mathrm{~Pb} /{ }^{204} \mathrm{~Pb}\right)_{\mathrm{i}}$ 为 $15.659 \sim 18.720,\left({ }^{207} \mathrm{~Pb} /{ }^{204} \mathrm{~Pb}\right)_{\mathrm{i}}$ 为 $15.344 \sim 15.656,\left({ }^{208} \mathrm{~Pb} /{ }^{204} \mathrm{~Pb}\right)_{\mathrm{i}}$ 为 $36.110 \sim 38.707$ (网络 版附表 3$)$. 岩体普遍具有较低的 $\varepsilon_{\mathrm{Nd}}(t) 、 \varepsilon_{\mathrm{Hf}}(t)$ 值和老
的 $t_{\mathrm{DM} 2}$ 年龄值: $\varepsilon_{\mathrm{Nd}}(t)$ 值介于 $-7.5 \sim-22.1, t_{\mathrm{DM} 2}$ 变化范围 为 $1.55 \sim 2.74 \mathrm{Ga} ; \varepsilon_{\mathrm{Hf}}(t)$ 值介于 $-1.9 \sim-35.7, \mathrm{Hf}$ 二阶段模 式年龄变化范围为 $1.29 \sim 3.38 \mathrm{Ga}$. 这些数据表明, 这 些花岗岩的源岩应主要为古老陆壳物质。岩体的 $\varepsilon_{\mathrm{Nd}}(t) 、 \varepsilon_{\mathrm{Hf}}(t)$ 以及两阶段模式年龄均显示出较大的 变化范围, 说明华北克拉通南缘晚中生代花岗岩的 岩浆源岩组成复杂. 而且, 随岩体年龄由老到新, $\varepsilon_{\mathrm{Nd}}(t) 、 \varepsilon_{\mathrm{Hf}}(t)$ 值均表现出增大的趋势, 二阶段模式年龄 由老到新变化(图8和9), 早期岩体 $\varepsilon_{\mathrm{Nd}}(t)=-7.6 \sim-22.1$, $\mathrm{Nd}$ 同位素二阶段模式年龄 $t_{\mathrm{DM} 2}=1.55 \sim 2.74 \mathrm{Ga}$, 晚期 岩体 $\varepsilon_{\mathrm{Nd}}(t)=-7.5 \sim-17.3, T_{\mathrm{DM} 2}=1.53 \sim 2.31 \mathrm{Ga} . \quad \mathrm{Hf}$ 同位 素组成则更加明显地反映了这一趋势, 早期岩 体 $\varepsilon_{\mathrm{Hf}}(t)=-3.4 \sim-35.1, T_{\mathrm{DM} 2}=1.46 \sim 3.38 \mathrm{Ga}$ ，晚期岩体 $\varepsilon_{\mathrm{Hf}}(t)=-1.9 \sim-20.8, T_{\mathrm{DM} 2}=1.29 \sim 2.49 \mathrm{Ga}$. 这种同位素组成 的变化, 反映晚期阶段岩浆源区有更多同位素组成 相对亏损的源岩物质加入.

\section{5 物质来源}

华北克拉通晚中生代花岗岩与成矿作用的成因 关系密切(Mao等, 2008; 朱赖民等, 2009; Chen和Wang, 2011; Li等, 2012a; Deng等, 2014). 岩浆源区的研究, 可 以为成矿物质源区的研究提供重要线索, 因此花岗岩 源岩组成的问题也是区域研究重点之一. 尽管华北 克拉通南缘晚中生代花岗岩具有较大的地球化学成 分变化范围和不同岩石类型, 但它们具有较为类似的 $\mathrm{Sr} 、 \mathrm{Nd} 、 \mathrm{Hf}$ 同位素组成(网络版附表2), 反应源区均以 古老的壳源物质为主. 大部分学者认为, 这些花岗岩 为华北克拉通南缘古老地壳(如熊耳群和太华群)部分 熔融形成, 并有新生岩石圈地幔及软流圈地幔物质的 加入(Hu等, 2012; Li N等, 2012; Gao等, 2014a, 2014b; Wang X X等, 2015). 还有一些观点认为, 花岗岩年轻 的同位素模式年龄代表其源区主要来自于俯冲到华 北克拉通下部的扬子北缘的地壳物质(李磊等, 2013; Bao等, 2014, 2017).

华北南缘晚中生代花岗岩总体上与太华群斜长角 闪岩和熊耳群火山岩的初始 ${ }^{87} \mathrm{Sr} /{ }^{86} \mathrm{Sr}$ 值 $(t=130 \mathrm{Ma})$ 范围 相似(图10)(Peng等, 2008; Xu X S等, 2009; He等, 2010; Wang等, 2010; Ni等, 2012), 但明显小于太华群片麻岩 和石英片岩(黄萱和吴利仁, 1990). 岩体的 $\varepsilon_{\mathrm{Nd}}(t)$ 值与太 华群斜长角闪岩 $\varepsilon_{\mathrm{Nd}}(t=130)$ 值相似, 尤其是早期阶段岩 

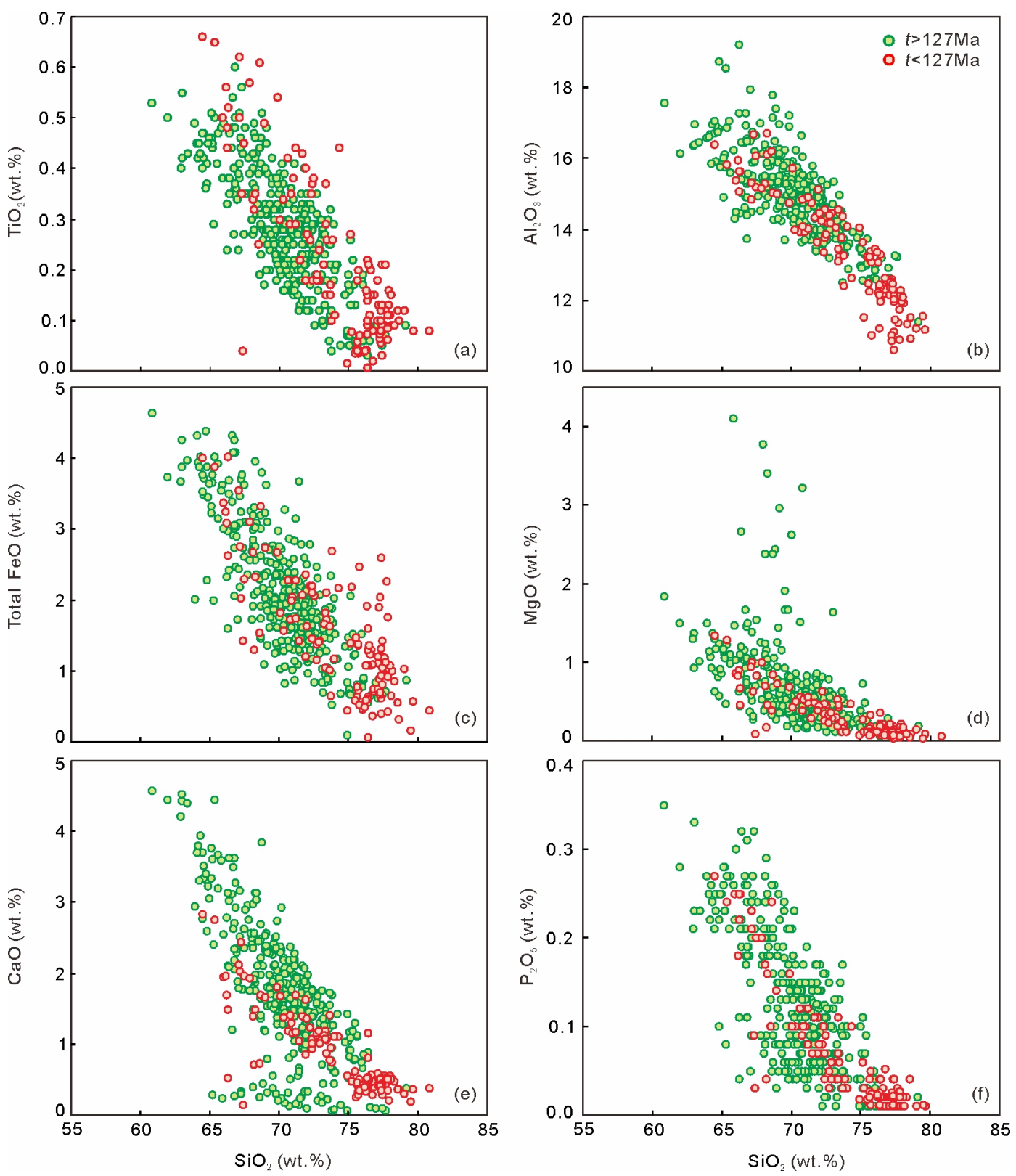

图 5 华北克拉通南缘晚中生代花岗岩主量元素地球化学特征 数据来源同图 3

体的 $\varepsilon_{\mathrm{Nd}}(t)$ 值部分落入太华群斜长角闪岩范围内, 但明 显高于太华群片麻岩和石英片岩和熊耳群火山岩的 $\mathrm{Nd}$ 同位素组成(图10). 太华群角闪岩和麻粒岩相变质 岩的原岩形成于新太古代到古元古代(2.84 2.26Ga), 并于 $2.1 \sim 1.8 \mathrm{Ga}$ 发生强烈变形变质作用 (Kröner 等, 1988; Wan等, 2006; Xu X S 等, 2009), 其同位素模式 年龄为 $2.8 \sim 3.2 \mathrm{Ga}$. 而主要盖层岩系熊耳群, 形成于
1.75 1.80Ga(Zhao T P等, 2004). 可见, 华北克拉通的 主要年龄记录与晚中生代花岗岩的同位素二阶段模 式年龄 $\left(T_{\mathrm{DM}(\mathrm{Nd}) 2}=1.55 \sim 2.74 \mathrm{Ga} ; T_{\mathrm{DM}(\mathrm{Hf}) 2}=1.29 \sim 3.38 \mathrm{Ga}\right)$ 相 似, 其中早期阶段花岗岩有近一半样品落入太华群Hf 同位素演化线内(图9). 这些同位素组成特征表明, 华 北克拉通南缘结晶基底可能是花岗岩的重要物源. 此 外, 花岗岩的二阶段模式年龄下限小于太华群的形成 

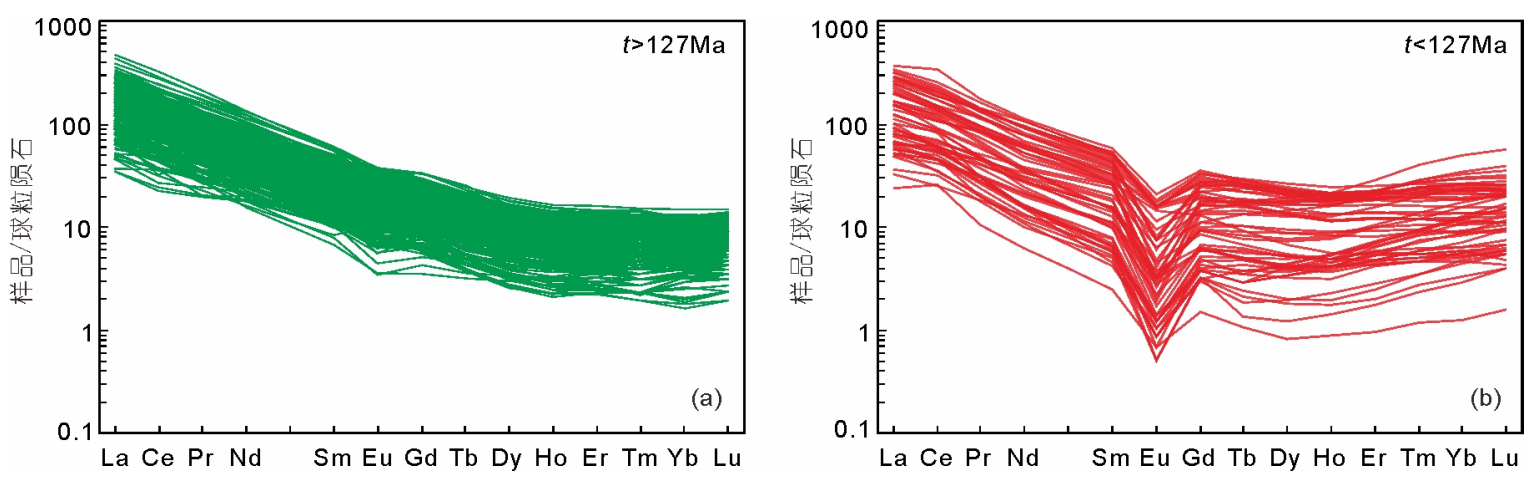

图 6 华北克拉通南缘晚中生代花岗岩稀土元素配分模式图

球粒陨石标准化值据Sun和McDonough(1989); 数据来源同图3

年龄, $\varepsilon_{\mathrm{Hf}}(t)$ 值也明显高于太华群和熊耳群地壳演化线 在晚中生代的变化范围, 尤其是晚期阶段花岗岩的 $\mathrm{Hf}$ 同位素组成几乎都落入太华群Hf同位素演化线以上 (图9), 表明只有结晶基底太华群变质岩部分熔融不能 形成符合全部华北南缘晚中生代花岗岩同位素特征 的熔体.

近年来, 对华北克拉通基底岩石高质量的锆石 $\mathrm{U}-\mathrm{Pb}$ 定年结果证明, 其最重要的年龄组是2.4 2.5Ga, 其比例远远高于其他年龄组, 同时还有 $1.7 \sim 1.9 \mathrm{Ga}$ 和 2.0 2.2Ga的年龄存在(Zhao等, 2001; Gao等, 2004; Xu 等, 2006). 继承锆石是示踪岩浆源区性质的有效指示 剂(Keay等, 1999). 锆石U-Pb年龄分析发现, 华北南缘 晚中生代花岗岩中的继承锆石年龄范围跨度很大, 分 布于3052 447Ma, 但主要由新太古代至古元古代(约 $2.7 \sim 1.7 \mathrm{Ga}$ )年龄组成(图11; 网络版附表4), 集中在太华 群强烈演化的地质历史阶段, 表明晚中生代花岗岩与 太华群具有密切的物源联系。

与华北克拉通南缘的地壳生长历史不同的是, 扬 子克拉通北缘地壳主要增生时间是在中元古-新元古 代(张少兵等, 2007; Ling等, 2008; Wang等, 2013)、早 古生代、晚三叠世也是重要的地壳生长阶段(Yang等, 2007). 这个年龄无论与华北南缘晚中生代花岗岩的 $\mathrm{Hf}$ 同位素二阶段模式年龄 $(1.29 \sim 3.38 \mathrm{Ga}$ )还是主要继承 锆石年龄范围(2.7 1.7Ga)均不能很好的对应, 表明扬 子克拉通北缘是花岗岩物源的可能性较小. 此外, 本 文收集了源于俯冲的扬子克拉通大陆岩石圈北缘物 质的大别晚中生代花岗岩类的 $\mathrm{Pb}$ 同位素组成与华北 南缘晚中生代花岗岩进行对比. 在图12中, 二者仅有 小部分重叠, 总体上也表现出不同的同位素组成特征.
综上所述, 华北南缘晚中生代花岗岩的主要源区 物质仍应该是以华北克拉通结晶基底为主, 并有更加 亏损的同位素组成物质的加入.

目前很多研究认为幔源岩浆在华北南缘晚中生 代岩浆-成矿作用中起了重要作用, 不仅提供热源, 还 在成岩-成矿过程中直接提供物源. Han等(2013)通过 对不同时期岩体中锆石 $\mathrm{Ce}^{4+} / \mathrm{Ce}^{3+}$ 比值变化规律, 认为 从老到新, 花岗质岩浆成岩成矿作用过程中地幔物质 的加入逐渐增多, 并对Mo、Au元素的成矿作用起了 关键作用. 朱赖民等(2009)通过对钼矿成矿流体稳定 同位素和 $\mathrm{Pb}$ 同位素组成以及成矿斑岩体和区域地层 岩石含矿性的研究揭示了, 矿床成岩成矿物质来自深 部, 为下地壳和上地幔混合源. 目前在华北南缘发现 的晚中生代基性岩浆岩有柡川西沟矿区发现的辉长 岩脉 $((148 \pm 2) \mathrm{Ma})$ 、黄龙铺辉绿岩脉 $((129 \pm 2) \mathrm{Ma})$ 、天

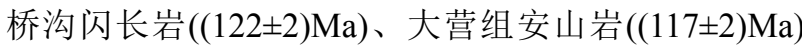
和伏牛山煌斑岩墙((117 \pm 2$) \mathrm{Ma})$ (数据来源见网络版附 表1). 它们的形成年龄与花岗岩的岩浆作用历史相对 应, 是华北南缘在晚中生代的大规模岩浆作用中壳幔 作用的直接证据. 在 $\left({ }^{87} \mathrm{Sr} r{ }^{86} \mathrm{Sr}\right)_{\mathrm{i}}-\varepsilon_{\mathrm{Nd}}(t)$ 图解上(图 10), 花 岗岩同位素数据主要落于太华群斜长角闪岩和地幔 物质混合线上,也表明岩体均经历了不同程度的壳幔 混合作用. 此外, 岩体的 $\mathrm{Nd}$ 和 $\mathrm{Hf}$ 同位素组成表现出随 着年龄由老到新, 逐渐向亏损的方向演化, 模式年龄 更加年轻的趋势. 尤其岩体的 $\mathrm{Hf}$ 同位素组成在 $127 \mathrm{Ma}$ 前后发生显著变化, 晚期阶段岩体的二阶段模式年龄 明显年轻,这一时期的基性岩浆作用规模也较早期增 大, 表明晚期阶段岩体中地幔作用较早期阶段显著增 强(图8和9). 因此可以认为在整个晚中生代岩浆作用 

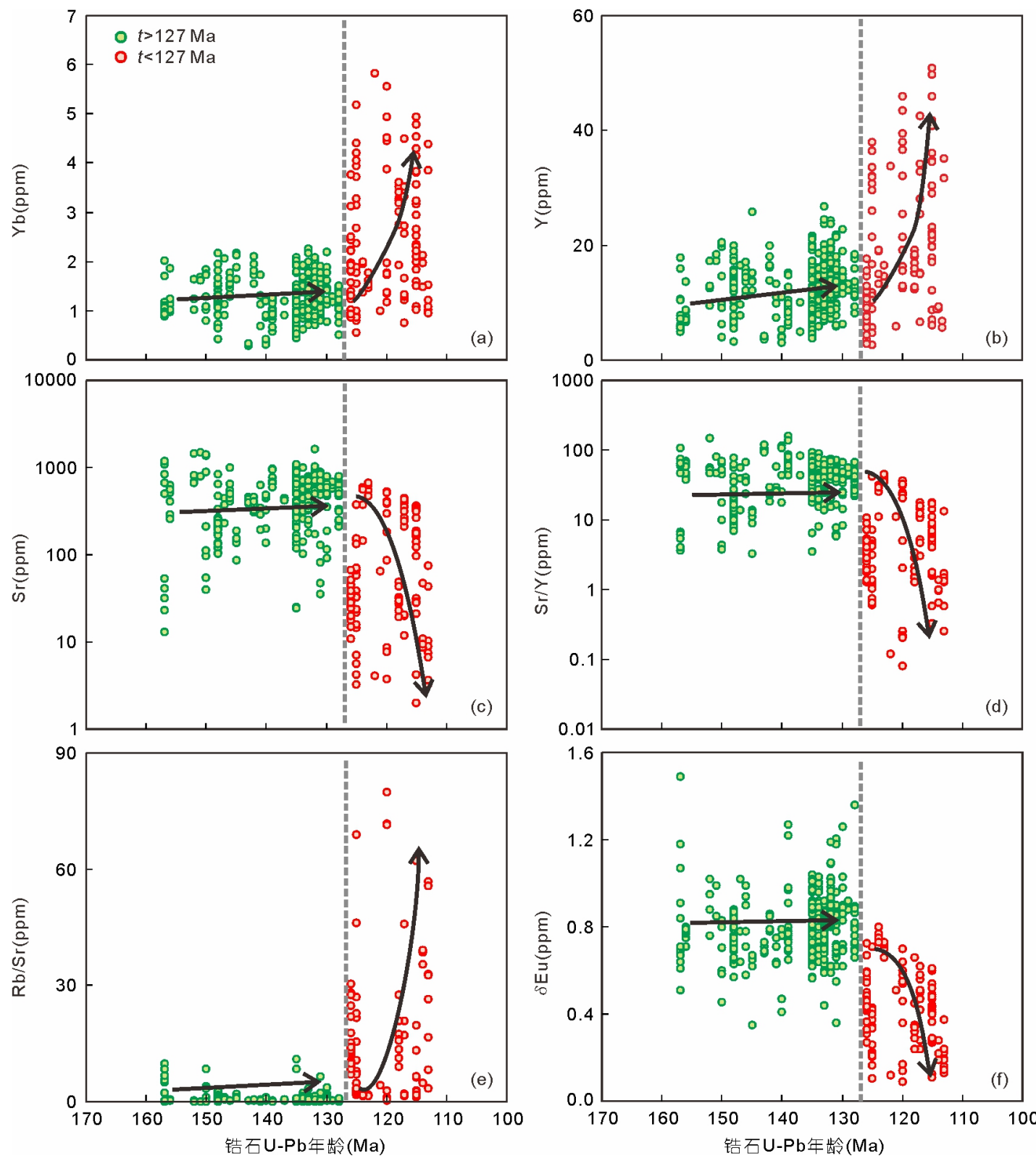

图 7 华北克拉通南缘晚中生代花岗岩微量元素地球化学特征 数据来源同图 3

过程中, 地幔物质在岩浆形成中不仅提供了热源, 也 提供了物源, 华北克拉通南缘地壳深部在晚中生代时 期经历了壳幔相互作用, 且随岩浆作用和构造运动的 演化, 地幔物质的作用更加强烈.

\section{6 地球动力学机制}

如前所述, 华北克拉通南缘晚中生代花岗岩的元 素地球化学和同位素组成特征, 在约 $127 \mathrm{Ma}$ 前后发生
了明显的改变(图6 9), 除了指示其源区特征的变化外, 也表明区域构造环境发生了强烈的变化.

地球化学数据表明早期阶段(158 128Ma)的花岗 岩一般为典型的I型花岗岩, 而晚期阶段(127 112Ma) 的花岗岩的地球化学特征则发生了明显的变化, 如 Sr、Eu的负异常, 相对早期阶段的具有更高的高场强 元素和重稀土元素含量, 更为富硅、富钾(图3 7). 多 数岩体具有较强分异演化的特征, 均属于 $\mathrm{A}$ 型花岗岩 

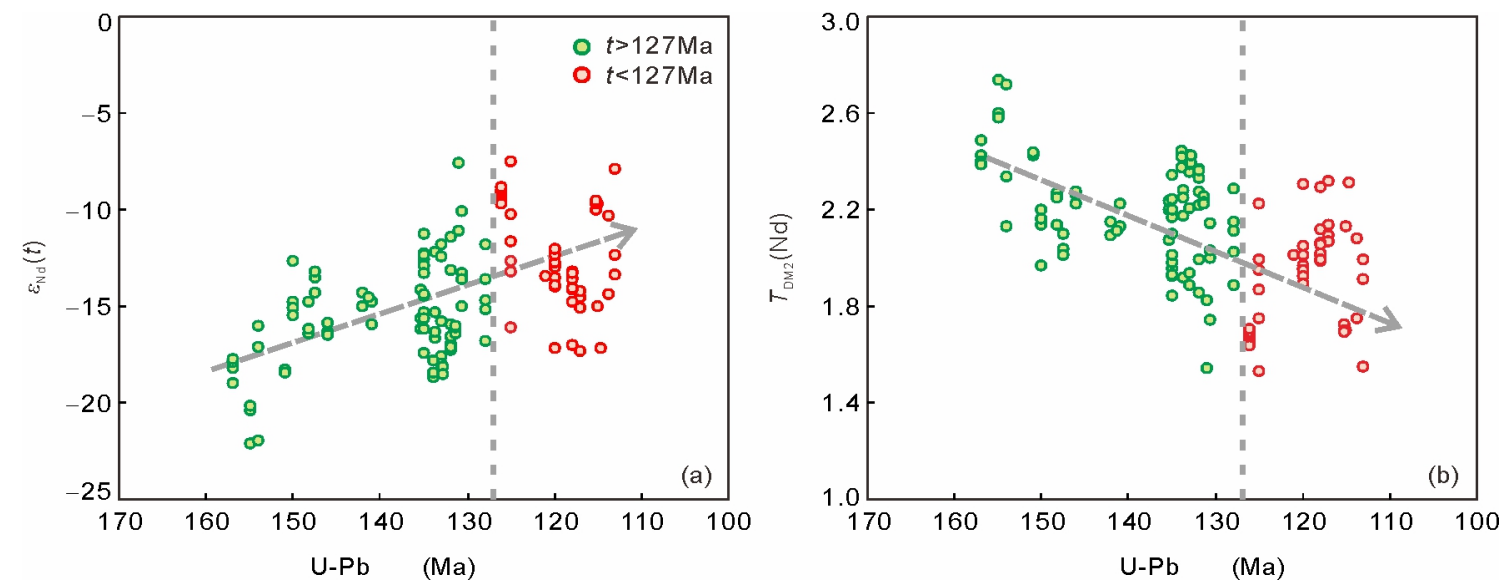

图 8 华北克拉通南缘晚中生代花岗岩的 $\mathrm{Nd}$ 同位素组成

数据来源同网络版附表 3

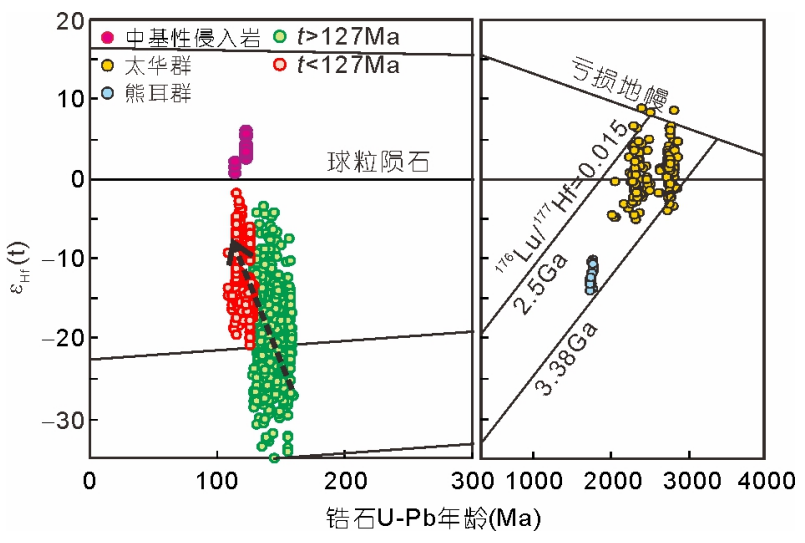

图 9 华北克拉通南缘晚中生代岩浆岩的 Hf同位素组成

数据来源: 戴宝章等(2009)、郭波等(2009)、姚军明等(2009)、高 昕宇等(2010,2012)、赵海杰等(2010a)、王晓霞等(2011)、Hu等 (2012)、Li H Y等(2012)、Li N等(2012)、Zhao等(2012)、齐秋菊等 (2012)、肖娥等(2012)、杨阳等(2012)、Yang等(2013)、曾令君等 (2013)、程知言等(2013)、柯昌辉等(2013)、Bao等 $(2014,2017)$ 、 Gao等 $(2014 a, 2014 b) 、 W a n g X$ X等 $(2015,2015) 、$ 段友强等(2015)、 张兴康等(2015)、王赛等(2016)

或高分异I型花岗岩, 反映了自 $127 \mathrm{Ma}$ 开始, 华北克拉 通南缘岩石圈开始进入强烈伸展减薄的构造环境(叶 会寿等, 2006; 戴宝章等, 2009; 李创举和包志伟, 2010; Yang等, 2013; Gao等, 2014a, 2014b)(图13).

岩石圈减薄可以使地壳岩石因减压而熔融 (Sylvester, 1998), 然而没有深部地幔物质或热源的供 给, 单纯的地壳减压熔融只能形成小规模的岩体, 缺 少足够的热量不可能形成大规模的岩浆活动(Roberts 和Clemens, 1993), 应有外来热源的加入才能使岩浆源

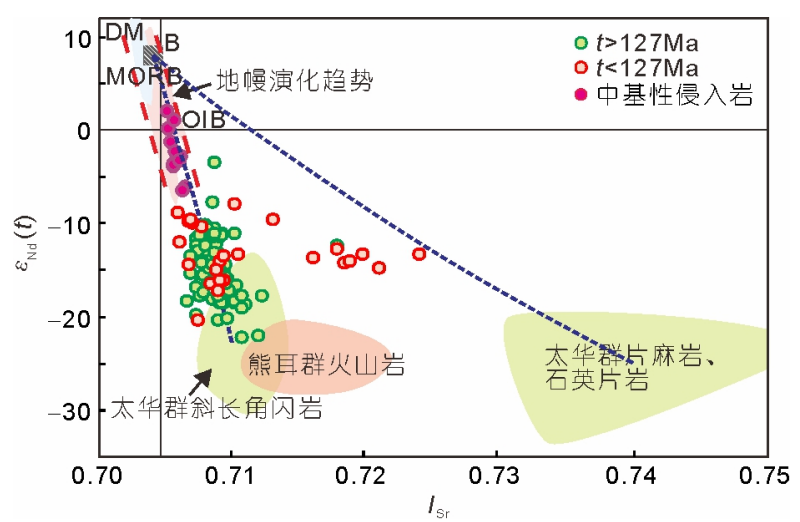

图 10 华北南缘晚中生代岩浆岩Sr-Nd同位素组成 图中太华群和熊耳群 $\varepsilon_{\mathrm{Nd}}(t)$ 和 $\left({ }^{87} \mathrm{Sr}{ }^{86} \mathrm{Sr}\right)_{\mathrm{i}}$ 使 $t=120$ 计算得到; 太华群 斜长角闪岩：黄萱和吴利仁(1990)、Ni等(2012); 太华群片麻岩 和石英片岩: 黄萱和吴利仁(1990); 熊耳群火山岩: He等(2010)、 Peng等(2008)、Wang等(2010); 幔源岩浆(B): Jahn等(1999); 亏损地 幔(DM)和地幔演化线: Hart和Zindler(1986); OIB和MORB: Sun和 McDonough(1989); 其他数据来源同网络版附表4

区大规模熔融(Miller等, 2003). 地幔与地壳之间的热 传递被认为是地壳熔融的主要方式, 而最有效的方式 是通过幔源岩浆底侵作用将地幔热传递到下地壳引 发熔融(Xu Y G 等, 2009). 地球物理资料显示, 华北克 拉通南缘下部存在着明显的地幔隆起, 呈北西走向, 大 致与中生代岩浆岩和钼、金多金属成矿带及区域深 大断裂在地表的展布范围吻合, 推测为地幔上涌的残 留, 反映地幔上涌和岩浆-成矿作用存在密切联系(袁 学诚, 1996). 对早期阶段(158 128Ma)花岗岩的物质来 源研究表明源区有幔源岩浆的加入, 且有少量基性岩 


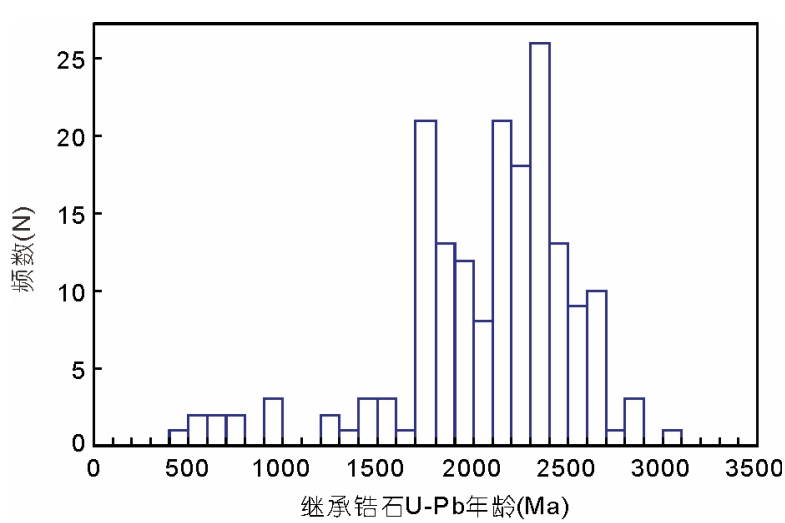

图 11 华北克拉通南缘晚中生代花岗岩继承锆石 U-Pb 年龄统计图

数据来源同网络版附表 4

脉发育. 奕川地区西沟铅锌矿区发现的辉长岩脉形 成于(147.5 \pm 1.7$) \mathrm{Ma}$ (包志伟等, 2009); 小秦岭黄龙铺地 区出露的辉绿岩形成于 $129 \mathrm{Ma}$, 且其元素和同位素地 球化学数据表现出来源于富集地幔的特征(赵海杰等, 2010b). 基性岩浆作用的发育表明这一时期,在华北克 拉通南缘, 软流圈上涌持续加热岩石圈底部形成的幔 源玄武质岩浆底侵使中下地壳熔融, 大量的长英质岩 浆沿断裂带上侵并形成花岗岩, 在这一过程中地幔物 质除了提供热源外, 还提供了物源(图13b).

晚期花岗岩的同位素组成更加亏损, 表明这个阶

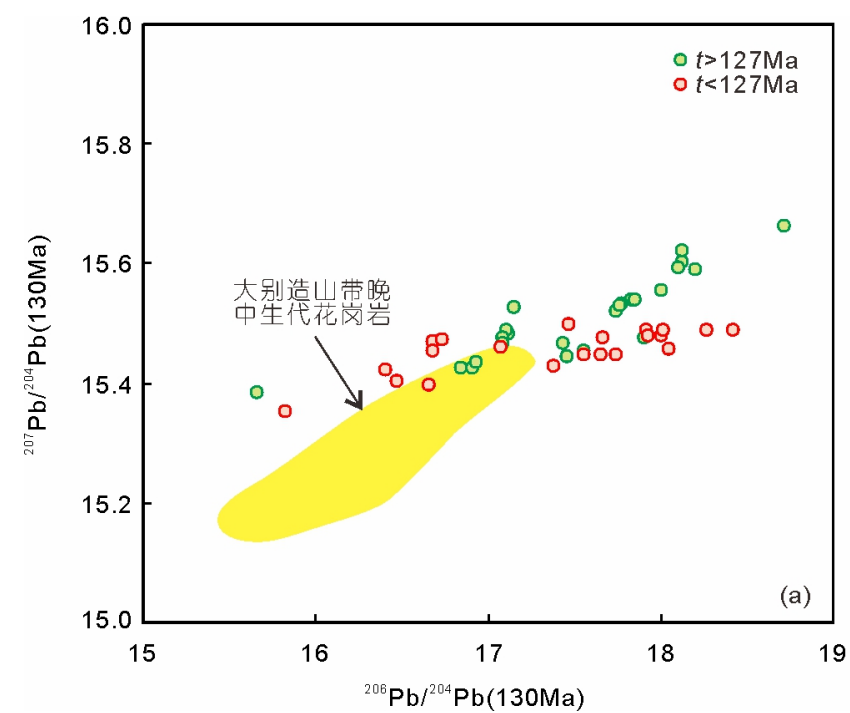

段岩体源区中幔源物质显著增加, 壳幔作用和基性岩 浆作用更加强烈(图13c). 王团华等(2008a)对小秦岭-熊 耳山金矿区的辉绿岩墙和煌斑岩墙样品进行SHRIMP 锆石U-Pb测年, 得到 $127 \mathrm{Ma}$ 和 $128 \mathrm{Ma}$ 两个测点的晚中 生代年龄数据. 其全岩地球化学特征显示, 这些岩墙 具 $\mathrm{Nb} 、 \mathrm{Ta} 、 \mathrm{Ti}$ 亏损和 $\mathrm{Sr}-\mathrm{Nd}$ 同位素富集的岛弧岩浆岩 特征, 岩浆可能来自于受到富钾熔体交代的上地幔的 部分熔融, 岩浆演化过程中明显受到壳源物质混染和 强烈的结晶分异作用(王团华等, 2008b, 2008c); 平顶 山早白严世大营组的中基性火山岩(117Ma, 谢桂青等, 2007)也具有富集的同位素组成, 被认为形成于华北古 老陆下岩石圈地幔和深俯冲的扬子下地壳混合源区的 部分熔融作用(李晓勇等, 2006)或早期俯冲组分改造 的富集地幔(谢桂青等, 2007); 高听宇(2012)报道了在 伏牛山花岗岩基中产出的数条宽度不等的煌斑岩墙 (117Ma), 样品的微量元素组成不具有 $\mathrm{Nb} 、 \mathrm{Ta} 、 \mathrm{Ti}$ 等高 场强元素负异常, 且具有相对亏损的 Sr-Nd-Hf同位素 组成, 显示出板内洋岛玄武岩的特征, 来源于亏损地幔 和富集地幔的混合, 软流圈地幔的贡献表明此时岩石 圈已经强烈伸展减薄, 煌斑岩作为岩墙侵位也是中上 部地壳伸展作用的明确标志(邵济安等, 2003). 与此同 时,在华北克拉通南缘西部的小秦岭地区发育变质核 杂岩构造. Zhang和Zheng(1999)结合野外切割关系和 构造测年, 限定了拆离断层的发育时限为135 123Ma,

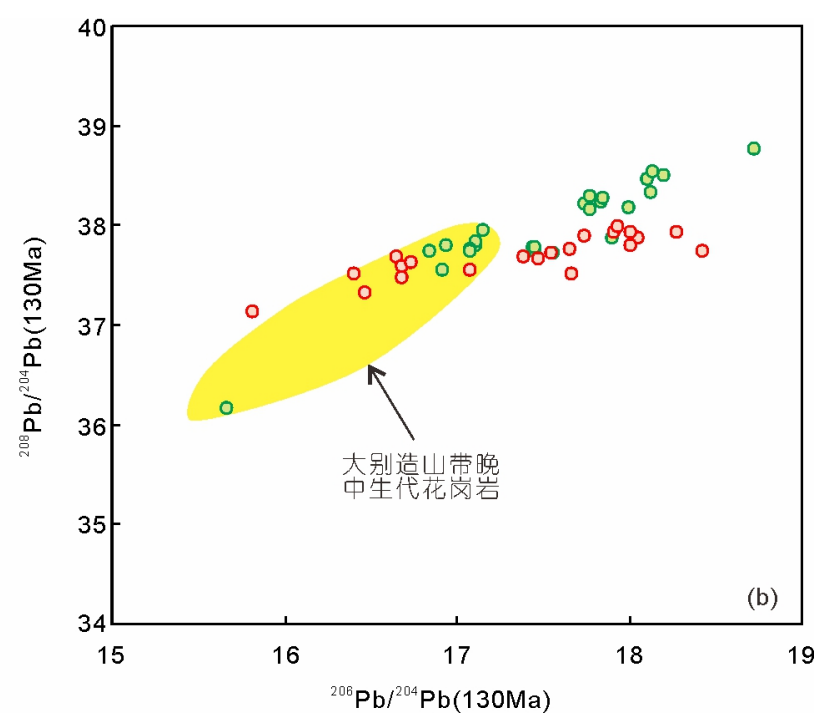

图 12 华北克拉通南缘晚中生代花岗岩与大别造山带中生代花岗岩 Pb同位素对比

大别造山带花岗岩数据来自: Zhang等(2002)、Wang等(2005)、Hou等(2007)、Huang等(2007, 2008)、胡芳芳等(2007)、Liu等(2008, 2009)、 $\mathrm{He}$ 等(2013) 

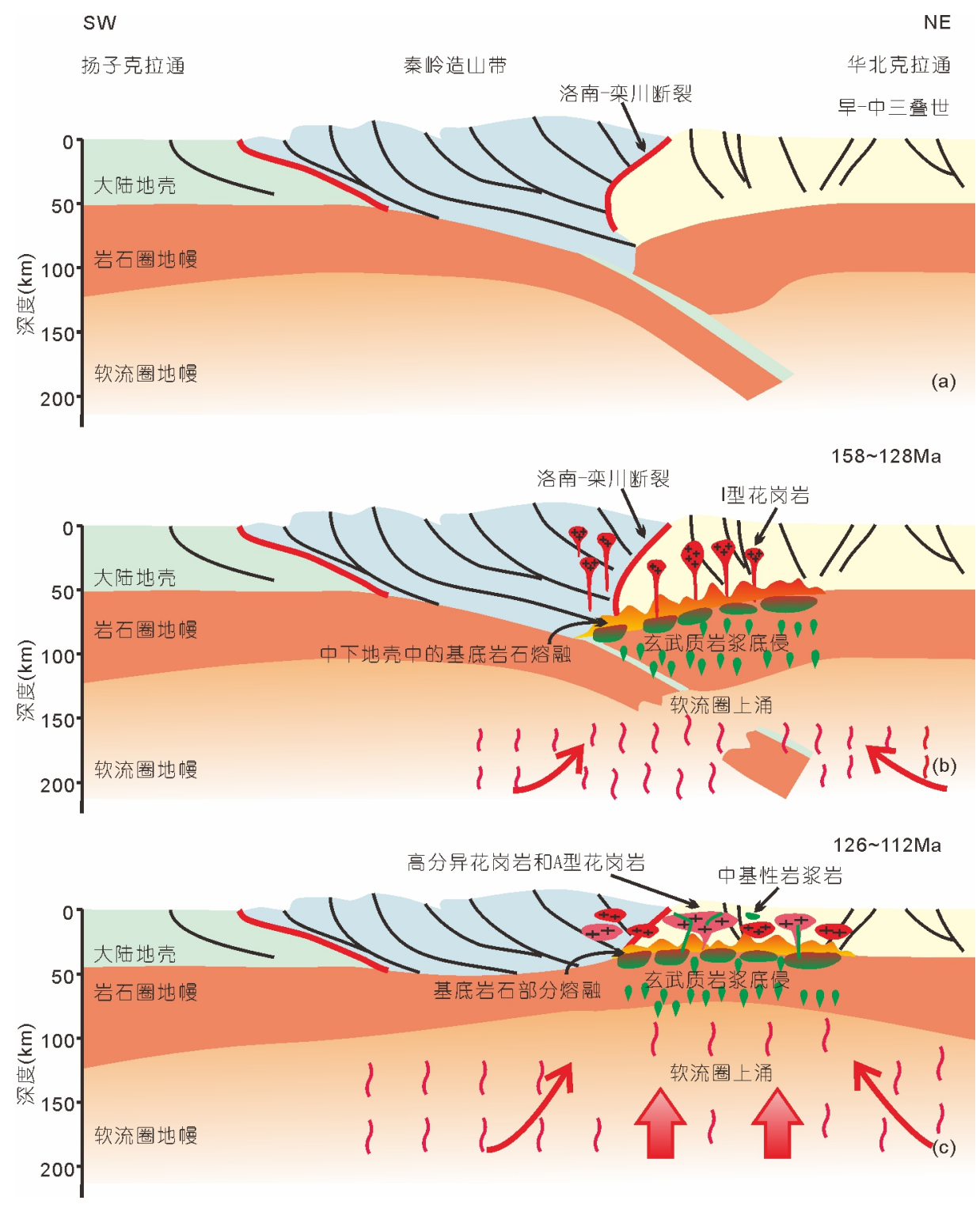

图 13 华北克拉通南缘晚中生代岩浆-构造演化模式图

修改自 Gao等(2014b)

而变质核杂岩内部垮塌伸展发育的时限为120 106Ma, 主要发生于116Ma. 这些基性-超基性岩和变质核杂岩 构造体系的发育都是指示岩石圈伸展减薄最直接的 地质证据.

综上所述, 华北克拉通南缘晚中生代的岩浆作用 从发育典型的I型花岗岩到发育A型花岗岩和高分异 花岗岩, 并伴随中基性岩浆的侵位, 这种岩石成因类 型和形成机制的演变表明岩石圈向强烈伸展减薄的 构造环境的转变. 年代学格架的研究表明, $127 \mathrm{Ma}$ 是
华北南缘晚中生代构造体制转变的一个关键时期. 值得注意的是, 华北克拉通南缘晚中生代岩浆作 用时限 158 112Ma, 距扬子克拉通与华北克拉通完成 碰撞拼合和相应超高压变质作用的时间(245 235Ma) 间隔已达约 $100 \mathrm{Ma}$ (张国伟等, 1996), 而对于一个碰撞 造山旋回, 从碰撞到伸展减薄及后碰撞岩浆活动, 一 般应在50Ma之内(Van Staal和De Roo, 1995; Finger等, 1997; Liégeois等, 1998; Waight等, 1998; Bea等, 1999; Van Wagoner等, 2002). 晚中生代的大面积岩浆侵位、 
火山喷发、Au-Ag-Mo多金属矿床的大规模成矿和伸 展构造, 在胶东半岛、太行山脉、鲁西、辽东和大别 地区也均有发育 (Zhang, 2012; Guo等, 2013; Tang Y J 等, 2013; Zhai和Santosh, 2013; Zhang等, 2013; Goldfarb 和Santosh, 2014; Yang Q Y等, 2014), 表明这一地质事 件并不独立存在于华北克拉通南缘, 而是在华北克拉 通东部乃至中国东部不同地区均有相同的地质响应, 受控于统一的动力学背景. 前人研究认为, 这一时期 中国东部发生的挤压-伸展构造、构造再活化、岩石 圈减薄和克拉通破坏与古太平洋板块漂移方向的大 幅度转折和俯冲速率的逐渐增强有密切的时空耦合 关系(Bartolini和Larson, 2001; 孙卫东等, 2008). 因此, 越来越多的研究认为华北克拉通的岩石圈伸展减薄 与古太平洋板块俯冲引起的亚洲大陆东部岩石圈之 下软流圈地幔的对流方向和速率的变化有关(Zhao等, 2007; Zhu等, 2010, 2012; 朱日祥等, 2011; Guo等, 2013; Tang Y J等, 2013; Goldfarb和Santosh, 2014)(图14).

古太平洋板块的平板俯冲对亚洲大陆的影响一 直延伸至近 $1300 \mathrm{~km}$ 的内陆, 从而引起了包括华北克拉 通在内的整个中国东部晚中生代的大规模岩浆作用 ( $\mathrm{Li}$ 和 $\mathrm{Li}, 2007$ ). 这种俯冲效应对中国东部岩石圈的影 响力向西可能只达华北克拉通的东部. 目前华北克拉 通南缘所在的秦岭造山带东部地区发育巨量晚中生 代花岗岩和多金属矿床, 而其西部没有, 就是一个很好 的证据. 受古太平洋板块俯冲的影响, 软流圈地幔受 到扰动而上涌加热, 促使岩石圈减薄, 特别是沿华北
克拉通周缘的深大断裂最为强烈, 如华北克拉通南缘 的洛南-奕川断裂(Tian和Zhao, 2011; Yang W等, 2012; Cai等, 2013; Ma等, 2014)(图14). 在华北克拉通南缘, 太平洋板块长距离俯冲对内陆的影响, 向西一直延续 至小秦岭地区(Li等, 2012a).

\section{7 结语}

华北克拉通南缘晚中生代岩浆-成矿事件频发, 尤 其是花岗岩出露遍布整个区域, 记录着该区岩石圈性 质和构造演化的重要信息. 精确的年代学和地球化学 研究结果显示, 花岗质岩浆作用持续近 $50 \mathrm{Ma}$, 经历了 2 个阶段的演化. 早期阶段的花岗岩(158 128Ma)为I型 花岗岩, 源岩以华北克拉通南缘古老结晶基底物质为 主, 并有幔源物质的参与. 晚期阶段的为 126 112Ma, 具有较强分异演化的特征, 均属于 $\mathrm{A}$ 型花岗岩或高分 异I型花岗岩, 形成于强烈伸展减薄的构造环境, 且花 岗岩源区中的地幔物质显著增多, 并伴随有同期基性 岩浆岩的产出, 表现出强烈的壳幔相互作用. 华北克 拉通南缘晚中生代岩浆作用由早到晚的演化趋势, 揭 示了区域构造体制由加厚的岩石圈向强烈伸展减薄 的构造环境的转变, 而127Ma前后是华北南缘晚中生 代构造体制转变的一个关键时期. 华北克拉通南缘晚 中生代强烈的岩浆-成矿-构造热事件并不是扬子与华 北克拉通碰撞后的产物, 而是与古太平洋板块在亚洲 大陆东部之下俯冲方向和速率的改变引发的整个中 国东部构造转折-岩石圈伸展减薄有关.

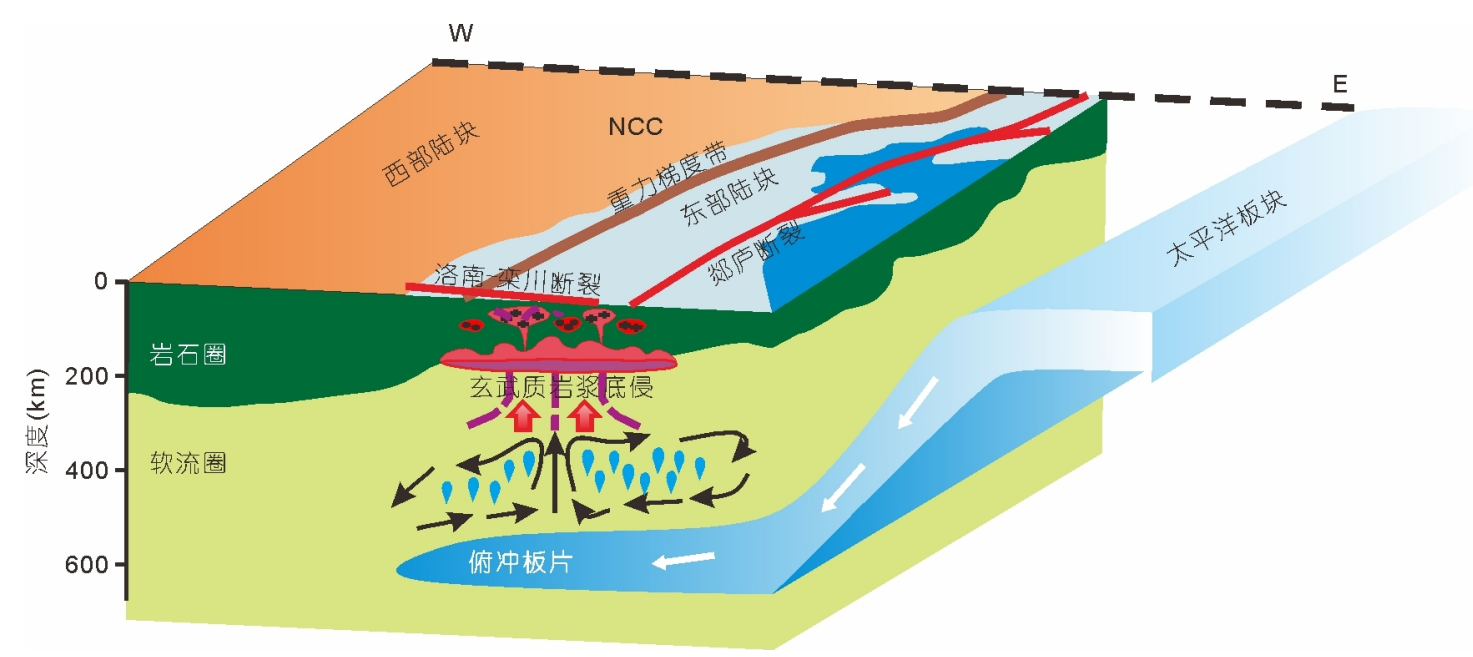

图 14 华北克拉通晚中生代构造演化的地球动力学机制

修改自 Li等(2012a)和 Gao等(2014a); NCC=North China Craton 
致谢华北克拉通南缘中生代花岗岩的研究过程中赵 振华研究员、包志伟研究员、姚军明研究员和王世炎教 授级高工给予了帮助和学术指导, 若名审稿人对本文提 出的建设性的修改建议, 在此一并表示感谢.

\section{参考文献}

包志伟, 李创举, 祁进平. 2009. 东秦岭栾川铅锌银矿田辉长岩锆石 SHRIMP U-Pb年龄及成矿时代. 岩石学报, 25: 2951-2956

陈衍景, 郭光军, 李欣. 1998. 华北克拉通花岗绿岩地体中中生代金 矿床的成矿地球动力学背景. 中国科学 $\mathrm{D}$ 辑: 地球科学, 28: 35-40

程知言, 胡建, 蒋少涌, 张遵忠, 戴宝章, 肖娥, 王艳芬. 2013. 河南鱼 池岭钼矿有关花岗岩锆石 $\mathrm{U}-\mathrm{Pb}$ 年龄和 $\mathrm{Hf}$ 同位素研究及其对成 矿时代的制约. 高校地质学报, (3): 403-414

戴宝章, 蒋少涌, 王孝否. 2009. 河南东沟钼矿花岗斑岩成因: 岩石 地球化学、锆石U-Pb年代学及 $\mathrm{Sr}-\mathrm{Nd}-\mathrm{Hf}$ 同位素制约. 岩石学报, 25: 2889-2901

段友强, 张正伟, 杨晓勇. 2015. 华北克拉通南缘张士英岩体大陆动 力学背景: 来自地球化学、锆石 $\mathrm{U}-\mathrm{Pb}$ 年龄和 $\mathrm{Hf}$ 同位素的证据. 岩 石学报, 31: 1995-2008

高昕宇, 赵太平, 高剑峰, 薛良伟, 原振雷. 2012. 华北陆块南缘小 秦岭地区早白垩世埃达克质花岗岩的 LA-ICP-MS 锆石U-Pb年 龄、Hf同位素和元素地球化学特征. 地球化学, 41: 303-325 高昕宇, 赵太平, 原振雷, 周艳艳, 高剑峰. 2010. 华北陆块南缘中生 代合峪花岗岩的地球化学特征与成因. 岩石学报, 26: 3485-3506 高昕宇. 2012. 华北克拉通南缘外方山和伏牛山地区早白严世花岗 岩成因研究. 博士学位论文. 北京: 中国科学院大学. 1-161

高亚龙, 张江明, 叶会寿, 孟芳, 周珂, 高阳. 2010. 东秦岭石窑沟斑 岩钼矿床地质特征及辉钼矿Re-Os年龄. 岩石学报, 26: 729-739

郭波, 朱赖民, 李埥, 弓虎军, 王建其. 2009. 华北陆块南缘华山和合 峪花岗岩岩体锆石 $\mathrm{U}-\mathrm{Pb}$ 年龄、 $\mathrm{Hf}$ 同位素组成与成岩动力学背 景. 岩石学报, 25: 265-281

郭敬辉, 陈福坤, 张晓曼, Siebel W, 翟明国. 2005. 苏鲁超高压带北 部中生代岩浆侵入活动与同碰撞-后碰撞构造过程: 锆石 $\mathrm{U}-\mathrm{Pb}$ 年 代学. 岩石学报, 4: 1281-1301

胡芳芳, 范宏瑞, 杨进辉, 万渝生, 刘敦一, 翟明国, 金成伟. 2004. 胶 东乳山含金石英脉的成矿年龄: 热液锆石SHRIMP法U-Pb测定. 科学通报, 49: 183-205

胡芳芳, 范宏瑞, 杨进辉, 翟明国, 谢烈文, 杨岳衡, 柳小明. 2007. 鲁 东昆崩山地区宫家辉长闪长岩成因: 岩石地球化学、锆石U-Pb 年代学与Hf同位素制约. 岩石学报, 23: 369-380

黄典豪, 侯增谦, 杨志明, 李振清, 许道学. 2009. 东秦岭钼矿带内碳 酸岩脉型钼(铅)矿床地质-地球化学特征、成矿机制及成矿构造 背景. 地质学报, 83: 1968-1984

黄凡, 罗照华, 卢欣祥, 陈必河, 杨宗峰. 2010. 河南汝阳地区竹园沟 钼矿地质特征、成矿时代及地质意义. 地质通报, 29: 1704-1711
黄萱, 吴利仁. 1990. 陕西地区岩浆岩 Nd、Sr同位素特征及其与大 地构造发展的联系. 岩石学报, (02): 1-11

焦建刚, 袁海潮, 何克, 孙涛, 徐刚, 刘瑞平. 2009. 陕西华县八里坡 钼矿床锆石 $\mathrm{U}-\mathrm{Pb}$ 和辉钼矿 $\mathrm{Re}-\mathrm{Os}$ 年龄及其地质意义. 地质学报, 83: $1159-1166$

柯昌辉, 王晓霞, 李金宝, 杨阳, 齐秋菊, 周晓宁. 2013. 华北地块 南缘黑山-木龙沟地区中酸性岩的锆石U-Pb年龄、岩石化学和 Sr-Nd-Hf同位素研究. 岩石学报, 29: 781-800

赖相濡. 2015. 熊耳山-外方山地区中生代花岗质岩石对金成矿作 用的约束. 硕士学位论文. 北京: 中国地质大学. 1-57

李创举, 包志伟. 2010. 河南舞阳南部张士英岩体的地球化学与成 因及其构造意义. 大地构造与成矿学, 34: 435-443

李厚民, 王登红, 王晓霞, 张长青, 李立兴. 2012. 华北地块南缘熊耳 山早中生代正长花岗岩-Shrimp 锆石U-Pb年龄、地球化学及意 义. 岩石矿物学杂志, 31: 771-782

李厚民, 叶会寿, 毛景文, 王登红, 陈毓川, 屈文俊, 杜安道. 2007. 小 秦岭金(钼)矿床辉钼矿铼-锇定年及其地质意义. 矿床地质, 26: $417-424$

李否, 孙卫志, 孟宪锋, 杨小芬, 张灯堂, 冯建之. 2013. 华北陆块南 缘崤山地区燕山期花岗岩地球化学、 $\mathrm{Sr}-\mathrm{Nd}-\mathrm{Pb}$ 同位素特征及其 地质意义. 岩石学报, 29: 2635-2652

李诺, 陈衍景, 孙亚莉, 胡海珠, 李晶, 张辉. 2009. 河南鱼池岭钼矿 床辉钼矿锞-锇同位素年龄及地质意义. 岩石学报, 25: 413-421

李诺, 孙亚莉, 李晶, 薛良伟, 李文博. 2008. 小秦岭大湖金钼矿床辉 钼矿钭锇同位素年龄及印支期成矿事件. 岩石学报, 24: 810-816 李铁刚, 武广, 陈毓川, 李宗彦, 杨金生, 乔翠杰. 2013. 豫西银家沟 杂岩体年代学、地球化学和岩石成因. 岩石学报, 29: 46-66

李晓勇, 范蔚茗, 王岳军, 夏斌, 范立勇. 2006. 华北克拉通南缘早白 严世中基性火山岩成因及其地质意义. 大地构造与成矿学, 30 : $220-230$

李正远, 叶会寿, 曹晶, 张兴康, 翟雷. 2014. 河南嵩县庙岭金矿区花 岗斑岩锆石 $\mathrm{U}-\mathrm{Pb}$ 年龄、岩石地球化学和 $\mathrm{Sr}-\mathrm{Nd}-\mathrm{Pb}$ 同位素特征. 岩石矿物学杂志, 33: 424-440

梁涛, 卢仁. 2015. 豫西崤山小妹河岩体LA-ICP-MS锆石U-Pb定年、 地球化学特征及地质意义. 地质通报, (8): 1526-1540

刘军, 武广, 贾守民, 李忠权, 孙亚莉, 钟伟. 2011. 豫西沙坡岭钼矿 床辉钼矿Re-Os同位素年龄及其地质意义. 矿物岩石, 31: 56-62

卢仁, 梁涛, 卢欣祥, 白风军, 成静亮, 温静静. 2014. 豫西崤山龙卧 沟岩体锆石 $\mathrm{U}-\mathrm{Pb}$ 年代学、地球化学特征及地质意义. 中国地质, 41: 756-772

马昌前, 杨坤光, 明厚利, 林广春. 2003. 大别山中生代地壳从挤压 转向伸展的时间: 花岗岩的证据. 中国科学 $\mathrm{D}$ 辑: 地球科学, 33: 817-827

倪智勇. 2009. 河南小秦岭大湖金-钼矿床地球化学及其矿床成因. 博士学位论文. 贵阳: 中国科学院地球化学研究所. 1-160 齐秋菊, 王晓霞, 柯昌辉, 李金宝. 2012. 华北地块南缘老牛山杂岩 
体时代、成因及地质意义-锆石年龄、 $\mathrm{Hf}$ 同位素和地球化学新 证据. 岩石学报, 28: 279-301

齐玥. 2014. 东秦岭地区晚中生代老君山岩体和太山庙岩体成因. 硕士学位论文. 合肥: 中国科学技术大学. 1-73

任纪舜. 1990. 中国东部及邻区大陆岩石圈的构造演化与成矿. 北 京: 科学出版社. 1-205

邵济安, 张永北, 张履桥, 牟保磊, 王佩瑛, 郭峰. 2003. 大同地区早 中生代煌斑岩-碳酸岩岩墙群. 岩石学报, 19: 93-104

孙卫东, 凌明星, 汪方跃, 丁兴, 胡艳华, 周继涁, 杨晓勇. 2008. 太平 洋板块俯冲与中国东部中生代地质事件. 矿物岩石地球化学通 报, 27: 218-225

唐克非. 2014. 华北克拉通南缘熊耳山地区金矿床时空演化、矿 床成因及成矿构造背景. 博士学位论文. 武汉: 中国地质大学. $1-162$

王赛, 叶会寿, 杨永强, 张兴康, 苏慧敏, 杨晨英. 2016. 豫西火神庙 岩体锆石U-Pb年代学、地球化学及 $\mathrm{Hf}$ 同位素组成. 中国科学: 地球科学, 41: 293-361

王团华, 毛景文, 王彦斌. 2008a. 小秦岭-熊耳山地区岩墙锆石 SHRIMP年代学研究——秦岭造山带岩石圈拆沉的证据. 岩石 学报, 24: 1273-1287

王团华, 毛景文, 谢桂青, 叶安旺, 李宗彦. 2008b. 小秦岭、熊耳山 金矿区中基性岩墙的岩石化学研究. 地学前缘, 15: 250-266

王团华, 毛景文, 谢桂青, 叶安旺, 李宗彦. 2008c. 小秦岭——熊耳山 地区中基性岩墙的 $\mathrm{Sr} 、 \mathrm{Nd} 、 \mathrm{~Pb}$ 同位素组成及其大地构造意义. 地质学报, 82: 1580-1591

王晓霞, 王涛, 齐秋菊, 李舢. 2011. 秦岭晚中生代花岗岩时空分布、 成因演变及构造意义. 岩石学报, 27: 1573-1593

王义天, 毛景文, 卢欣祥. 2001. 嵩县祁雨沟金矿成矿时代的 ${ }^{40} \mathrm{Ar}-{ }^{39} \mathrm{Ar}$ 年代学证据. 地质论评, 47: 551-555

吴福元, 李献华, 杨进辉, 郑永飞. 2007. 花岗岩成因研究的若干问 题. 岩石学报, 23: 1217-1238

吴福元, 杨进辉, 柳小明. 2005. 辽东半岛中生代花岗质岩浆作用的 年代学格架. 高校地质学报, 11: 305-317

向君峰. 2009. 河南中部张士英岩体的成因研究. 硕士学位论文. 北 京: 中国地质大学. 1-74

肖娥, 胡建, 张遵忠, 戴宝章, 王艳芬, 李海勇. 2012. 东秦岭花山复 式岩基中高坪与金山庙花岗岩体岩石地球化学、锆石 $\mathrm{U}-\mathrm{Pb}$ 年代 学和Lu-Hf同位素组成. 岩石学报, 28: 4031-4046

肖鸿, 魏俊浩, 谭俊, 李欢, 贾盼盼, 石文杰, 杜保峰. 2012. 小秦岭地 区早白严世酸性侵入岩地球化学特征及构造环境. 地质科技情 报, 31: 39-48

谢桂青, 毛景文, 李瑞玲, 叶会寿, 张毅星, 万渝生, 李厚民, 高建京, 郑熔芬. 2007. 东秦岭宝丰盆地大营组火山岩SHRIMP定年及其 意义. 岩石学报, 23: 2387-2396

许成, 宋文否, 漆亮, 王林均. 2009. 黄龙铺钼矿田含矿碳酸岩地球 化学特征及其形成构造背景. 岩石学报, 25: 422-430
许道学. 2009. 河南鱼池岭斑岩钼矿床——岩浆作用与矿床成因. 硕士学位论文. 北京: 北京科技大学. 1-83

杨阳, 王晓霞, 柯昌辉, 李金宝. 2012. 豫西南泥湖矿集区石宝沟花 岗岩体的锆石 $\mathrm{U}-\mathrm{Pb}$ 年龄、岩石地球化学及 $\mathrm{Hf}$ 同位素组成. 中国 地质, 39: 1525-1542

姚军明, 赵太平, 李晶, 孙亚莉, 原振雷, 陈伟, 韩军. 2009. 河南祁雨 沟金成矿系统辉钼矿Re-Os年龄和锆石 U-Pb 年龄及 $\mathrm{Hf}$ 同位素 地球化学. 岩石学报, 25: 374-384

叶会寿, 毛景文, 李永峰, 郭保健, 张长青, 刘王君, 间全人, 刘国印. 2006. 东秦岭东沟超大型斑岩钼矿 SHRIMP锆石U-Pb和辉钼矿 Re-Os年龄及其地质意义. 地质学报, 80: 1078-1088

叶会寿, 毛景文, 徐林刚, 高建京, 谢桂清, 李向前, 何春芬. 2008. 豫 西太山庙铝质 $\mathrm{A}$ 型花岗岩SHRIMP锆石U-Pb年龄及其地球化学 特征. 地质论评, 54: 699-711

袁学诚. 1996. 中国地球物理图集. 北京: 地质出版社. 1-200

张灯堂, 冯建之, 李否, 孟宪锋, 何进, 刘宗彦, 徐文超. 2015. 华北克 拉通南缘后大陆碰撞背景下的岩石圈演化及金、钿成矿规律探 讨. 大地构造与成矿学, (2): 300-314

张国伟, 郭安林, 刘福田, 孟庆任, 肖庆辉. 1996. 秦岭造山带三维结 构及其动力学分析. 中国科学 $\mathrm{D}$ 辑: 地球科学, (增刊 1): 1-6

张少兵, 郑永飞, 吴元保. 2007. 华南陆核的生长和再造: 锆石 U-Pb 年龄和 Hf-O 同位素研究. 岩石学报, 23: 393-402

张兴康, 叶会寿, 李正远, 曹晶, 王小雨. 2015. 小秦岭华山复式岩基 大夫峪岩体锆石 $\mathrm{U}-\mathrm{Pb}$ 年龄、 $\mathrm{Hf}$ 同位素和地球化学特征. 矿床地 质, 34: 235-260

曾令君, 星玉才, 周栋, 赵太平, 姚军明, 包志伟. 2013. 河南卢氏八 宝山花岗斑岩LA-ICP-MS锆石U-Pb年龄和Hf同位素组成特征. 大地构造与成矿学, 37: 65-77

赵海杰, 毛景文, 叶会寿, 侯可军, 梁慧山. 2010a. 陕西洛南县石家 湾钼矿相关花岗斑岩的年代学及岩石成因: 锆石 $\mathrm{U}-\mathrm{Pb}$ 年龄及 $\mathrm{Hf}$ 同位素制约. 矿床地质, 29: 143-157

赵海杰, 毛景文, 叶会寿, 谢桂青, 杨宗喜. 2010b. 陕西黄龙铺地区 碱性花岗斑岩及辉绿岩的年代学与地球化学: 岩石成因及其构 造环境示踪. 中国地质, 37: 12-27

赵子福, 郑永飞. 2009. 俯冲大陆岩石圈重熔: 大别-苏鲁造山带中 生代岩浆岩成因. 中国科学 D辑: 地球科学, 7: 888-909

周红升, 马昌前, 张超, 陈玲, 张金阳, 余振兵. 2008. 华北克拉通南 缘泌阳春水燕山期铝质 $\mathrm{A}$ 型花岗岩类: 年代学、地球化学及其 启示. 岩石学报, 24: 49-64

周珂. 2008. 豫西鱼池岭斑岩型锄矿床的地质地球化学特征与成因 研究. 硕士学位论文. 北京: 中国地质大学. 1-90

朱赖民, 张国伟, 郭波, 李粼. 2008. 东秦岭金堆城大型斑岩钼矿 床 LA-ICP-MS锆石 U-Pb定年及成矿动力学背景. 地质学报, 82: 204-220

朱赖民, 张国伟, 郭波, 李彝. 2009. 华北地块南缘钼矿床黄铁矿流 体包裹体氦、氩同位素体系及其对成矿动力学背景的示踪. 科 
学通报, 54: 1725-1735

朱日祥, 陈凌, 吴福元, 刘俊来. 2011. 华北克拉通破坏的时间、范 围与机制. 中国科学: 地球科学, 41: 583-592

Bao Z W, Sun W D, Zartman R E, Yao J M, Gao X Y. 2017. Recycling of subducted upper continental crust: Constraints on the extensive molybdenum mineralization in the Qinling-Dabie orogen. Ore Geol Rev, 81: 451-465

Bao Z W, Wang C Y, Zhao T P, Li C Y, Gao X Y. 2014. Petrogenesis of the Mesozoic granites and Mo mineralization of the Luanchuan ore field in the East Qinling Mo mineralization belt, Central China. Ore Geol Rev, 57: 132-153

Bartolini A, Larson R L. 2001. Pacific microplate and the Pangea supercontinent in the Early to Middle Jurassic. Geology, 29: 735-738

Basu A R, Wang J, Huang W, Xie G, Tatsumoto M. 1991. Major element, $\mathrm{REE}$, and $\mathrm{Pb}, \mathrm{Nd}$ and $\mathrm{Sr}$ isotopic geochemistry of Cenozoic volcanic rocks of eastern China: Implications for their origin from suboceanictype mantle reservoirs. Earth Planet Sci Lett, 105: 149-169

Bea F, Montero P, Molina J F. 1999. Mafic precursors, peraluminous granitoids, and late lamprophyres in the Avila batholith: A model for the generation of Variscan batholiths in Iberia. J Geol, 107: 399-419

Cai Y C, Fan H R, Santosh M, Liu X, Hu F F, Yang K F, Lan T G, Yang Y H, Liu Y. 2013. Evolution of the lithospheric mantle beneath the southeastern North China Craton: Constraints from mafic dikes in the Jiaobei terrain. Gondwana Res, 24: 601-621

Chen Y J, Wang Y. 2011. Fluid inclusion study of the Tangjiaping Mo deposit, Dabie Shan, Henan Province: Implications for the nature of the porphyry systems of post-collisional tectonic settings. Int Geol Rev, 53: 635-655

Davis G A, Darby B J, Yadong Z, Spell T L. 2002. Geometric and temporal evolution of an extensional detachment fault, Hohhot metamorphic core complex, Inner Mongolia, China. Geology, 30: 1003-1006

Deng J, Gong Q, Wang C, Carranza E J M, Santosh M. 2014. Sequence of Late Jurassic-Early Cretaceous magmatic-hydrothermal events in the Xiong'ershan region, Central China: An overview with new zircon $\mathrm{U}-\mathrm{Pb}$ geochronology data on quartz porphyries. J Asian Earth Sci, 79: $161-172$

Ding L X, Ma C Q, Li J W, Robinson P T, Deng X D, Zhang C, Xu W C. 2011. Timing and genesis of the adakitic and shoshonitic intrusions in the Laoniushan complex, southern margin of the North China Craton: Implications for post-collisional magmatism associated with the Qinling Orogen. Lithos, 126: 212-232

Fan W M, Zhang H F, Baker J, Jarvis K E, Mason P R D, Menzies M A. 2000. On and off the north China Craton: Where is the Archaean keel? J Petrol, 41: 933-950

Finger F, Roberts M P, Haunschmid B, Schermaier A, Steyrer H P. 1997. Variscan granitoids of central Europe: Their typology, potential sources and tectonothermal relations. Mineral Petrol, 61: 67-96 Gao S, Rudnick R L, Yuan H L, Liu X M, Liu Y S, Xu W L, Ling W L, Ayers J, Wang X C, Wang Q H. 2004. Recycling lower continental crust in the North China craton. Nature, 432: 892-897

Gao X Y, Zhao T P, Bao Z W, Yang A Y. 2014a. Petrogenesis of the early Cretaceous intermediate and felsic intrusions at the southern margin of the North China Craton: Implications for crust-mantle interaction. Lithos, 206-207: 65-78

Gao X Y, Zhao T P, Chen W T. 2014b. Petrogenesis of the early Cretaceous Funiushan granites on the southern margin of the North China Craton: Implications for the Mesozoic geological evolution. J Asian Earth Sci, 94: 28-44

Goldfarb R J, Santosh M. 2014. The dilemma of the Jiaodong gold deposits: Are they unique? Geosci Front, 5: 139-153

Guo P, Santosh M, Li S. 2013. Geodynamics of gold metallogeny in the Shandong Province, NE China: An integrated geological, geophysical and geochemical perspective. Gondwana Res, 24: 1172-1202

Hacker B R, Ratschbacher L, Webb L, Ireland T, Walker D, Shuwen D. 1998. $\mathrm{U} / \mathrm{Pb}$ zircon ages constrain the architecture of the ultrahighpressure Qinling-Dabie Orogen, China. Earth Planet Sci Lett, 161: 215-230

Han Y G, Zhang S H, Pirajno F, Zhou X W, Zhao G C, Qü W J, Liu S H, Zhang J M, Liang H B, Yang K. 2013. U-Pb and Re-Os isotopic systematics and zircon $\mathrm{Ce}^{4+} / \mathrm{Ce}^{3+}$ ratios in the Shiyaogou Mo deposit in eastern Qinling, central China: Insights into the oxidation state of granitoids and $\mathrm{Mo}(\mathrm{Au})$ mineralization. Ore Geol Rev, 55: 29-47

Hart S R, Zindler A. 1986. In search of a bulk-Earth composition. Chem Geol, 57: 247-267

He Y H, Zhao G C, Sun M, Han Y G. 2010. Petrogenesis and tectonic setting of volcanic rocks in the Xiaoshan and Waifangshan areas along the southern margin of the North China Craton: Constraints from bulk-rock geochemistry and $\mathrm{Sr}-\mathrm{Nd}$ isotopic composition. Lithos, 114: 186-199

He Y S, Li S G, Hoefs J, Kleinhanns I C. 2013. Sr-Nd-Pb isotopic compositions of Early Cretaceous granitoids from the Dabie orogen: Constraints on the recycled lower continental crust. Lithos, 156-159: 204-217

Hou M L, Jiang Y H, Jiang S Y, Ling H F, Zhao K D. 2007. Contrasting origins of late Mesozoic adakitic granitoids from the northwestern Jiaodong Peninsula, east China: Implications for crustal thickening to delamination. Geol Mag, 144: 619-631

Hu J, Jiang S Y, Zhao H X, Shao Y, Zhang Z Z, Xiao E, Wang Y F, Dai B Z, Li H Y. 2012. Geochemistry and petrogenesis of the Huashan granites and their implications for the Mesozoic tectonic settings in the Xiaoqinling gold mineralization belt, NW China. J Asian Earth Sci, 56: 276-289 
Huang F, Li S, Dong F, He Y, Chen F. 2008. High-Mg adakitic rocks in the Dabie orogen, central China: Implications for foundering mechanism of lower continental crust. Chem Geol, 255: 1-13

Huang F, Li S G, Dong F, Li Q L, Chen F K, Wang Y, Yang W. 2007. Recycling of deeply subducted continental crust in the Dabie Mountains, central China. Lithos, 96: 151-169

Huang X L, Niu Y, Xu Y G, Yang Q J, Zhong J W. 2010. Geochemistry of TTG and TTG-like gneisses from Lushan-Taihua complex in the southern North China Craton: Implications for late Archean crustal accretion. Precambrian Res, 182: 43-56

Huang X L, Wilde S A, Yang Q J, Zhong J W. 2012. Geochronology and petrogenesis of gray gneisses from the Taihua Complex at Xiong'er in the southern segment of the Trans-North China Orogen: Implications for tectonic transformation in the Early Paleoproterozoic. Lithos, 134-135: 236-252

Jahn B, Wu F Y, Lo C H, Tsai C H. 1999. Crust-mantle interaction induced by deep subduction of the continental crust: Geochemical and $\mathrm{Sr}-\mathrm{Nd}$ isotopic evidence from post-collisional mafic-ultramafic intrusions of the northern Dabie complex, central China. Chem Geol, 157: 119-146

Keay S, Steele D, Compston W. 1999. Identifying granite sources by SHRIMP U-Pb zircon geochronology: An application to the Lachlan foldbelt. Contrib Mineral Petrol, 137: 323-341

Kröner A, Compston W, Zhang G W, Guo A L, Todt W. 1988. Age and tectonic setting of Late Archean greenstone-gneiss terrain in Henan Province, China, as revealed by single-grain zircon dating. Geology, 16: $211-215$

Kusky T M, Windley B F, Zhai M G. 2007. Tectonic evolution of the North China Block: From orogen to craton to orogen. In: Zhai M G, Windley B F, Kusky T M, Meng Q R, eds. Mesozoic Sub-Continental Lithospheric Thinning Under Eastern Asia. Geological Society Special Publications. 1-34

Li H Y, Wang X X, Ye H S, Yang L. 2012. Emplacement ages and petrogenesis of the Molybdenum-bearing granites in the Jinduicheng area of East Qinling, China: Constraints from zircon $\mathrm{U}-\mathrm{Pb}$ ages and $\mathrm{Hf}$ isotopes. Acta Geol Sin-Engl Ed, 86: 661-679

Li J W, Bi S J, Selby D, Chen L, Vasconcelos P, Thiede D, Zhou M F, Zhao X F, Li Z K, Qiu H N. 2012a. Giant Mesozoic gold provinces related to the destruction of the North China craton. Earth Planet Sci Lett, 349-350: 26-37

Li J W, Li Z K, Zhou M F, Chen L, Bi S J, Deng X D, Qiu H N, Cohen B, Selby D, Zhao X F. 2012b. The Early Cretaceous Yangzhaiyu Lode gold deposit, north China Craton: A link between craton reactivation and gold veining. Econ Geol, 107: 43-79

Li N, Chen Y J, Pirajno F, Gong H J, Mao S D, Ni Z Y. 2012. LA-ICP-MS zircon $\mathrm{U}-\mathrm{Pb}$ dating, trace element and $\mathrm{Hf}$ isotope geochemistry of the
Heyu granite batholith, eastern Qinling, central China: Implications for Mesozoic tectono-magmatic evolution. Lithos, 142-143: 34-47

Li Z X, Li X H. 2007. Formation of the 1300-km-wide intracontinental orogen and postorogenic magmatic province in Mesozoic South China: A flat-slab subduction model. Geology, 35: 179

Liégeois J P, Navez J, Hertogen J, Black R. 1998. Contrasting origin of post-collisional high-K calc-alkaline and shoshonitic versus alkaline and peralkaline granitoids. The use of sliding normalization. Lithos, 45: $1-28$

Ling W L, Ren B F, Duan R C, Liu X M, Mao X W, Peng L H, Liu Z X, Cheng J P, Yang H M. 2008. Timing of the Wudangshan, Yaolinghe volcanic sequences and mafic sills in South Qinling: U-Pb zircon geochronology and tectonic implication. Chin Sci Bull, 53: 2192-2199

Liu D, Wilde S A, Wan Y, Wang S, Valley J W, Kita N, Dong C, Xie H, Yang C, Zhang Y, Gao L. 2009. Combined U-Pb, hafnium and oxygen isotope analysis of zircons from meta-igneous rocks in the southern North China Craton reveal multiple events in the Late Mesoarchean-Early Neoarchean. Chem Geol, 261: 140-154

Liu J L, Davis G A, Lin Z Y, Wu F Y. 2005. The Liaonan metamorphic core complex, Southeastern Liaoning Province, North China: A likely contributor to Cretaceous rotation of Eastern Liaoning, Korea and contiguous areas. Tectonophysics, 407: 65-80

Liu S, Hu R Z, Gao S, Feng C X, Qi Y Q, Wang T, Feng G Y, Coulson I M. 2008. U-Pb zircon age, geochemical and $\mathrm{Sr}-\mathrm{Nd}-\mathrm{Pb}-\mathrm{Hf}$ isotopic constraints on age and origin of alkaline intrusions and associated mafic dikes from Sulu orogenic belt, Eastern China. Lithos, 106: 365-379

Ma L, Jiang S Y, Hou M L, Dai B Z, Jiang Y H, Yang T, Zhao K D, Pu W, Zhu Z Y, Xu B. 2014. Geochemistry of Early Cretaceous calc-alkaline lamprophyres in the Jiaodong Peninsula: Implication for lithospheric evolution of the eastern North China Craton. Gondwana Res, 25: $859-872$

Maniar P D, Piccoli P M. 1989. Tectonic discrimination of granitoids. Geol Soc Am Bull, 101: 635-643

Mao J W, Pirajno F, Xiang J F, Gao J J, Ye H S, Li Y F, Guo B J. 2011. Mesozoic molybdenum deposits in the east Qinling-Dabie orogenic belt: Characteristics and tectonic settings. Ore Geol Rev, 43: 264-293

Mao J W, Xie G Q, Bierlein F, Qü W J, Du A D, Ye H S, Pirajno F, Li H M, Guo B J, Li Y F, Yang Z Q. 2008. Tectonic implications from Re-Os dating of Mesozoic molybdenum deposits in the East Qinling-Dabie orogenic belt. Geochim Cosmochim Acta, 72: 4607-4626

Mao J W, Xie G Q, Pirajno F, Ye H S, Wang Y B, Li Y F, Xiang J F, Zhao H J. 2010. Late Jurassic-Early Cretaceous granitoid magmatism in Eastern Qinling, central-eastern China: SHRIMP zircon U-Pb ages and tectonic implications. Aust J Earth Sci, 57: 51-78 
Menzies M A, Fan W M, Zhang M. 1993. Palaeozoic and Cenozoic lithoprobes and the loss of $>120 \mathrm{~km}$ of Archaean lithosphere, SinoKorean craton, China. Geol Soc Lond Spec Publ, 76: 71-81

Middlemost E A K. 1985. Magmas and Magmatic Rocks: An Introduction to Igneous Petrology. London: Longman Group. 266

Miller C F, McDowell S M, Mapes R W. 2003. Hot and cold granites? Implications of zircon saturation temperatures and preservation of inheritance. Geology, 31: 529-532

Ni Z Y, Chen Y J, Li N, Zhang H. 2012. Pb-Sr-Nd isotope constraints on the fluid source of the Dahu Au-Mo deposit in Qinling Orogen, central China, and implication for Triassic tectonic setting. Ore Geol Rev, 46: 60-67

Peccerillo A, Taylor S R. 1976. Geochemistry of eocene calc-alkaline volcanic rocks from the Kastamonu area, Northern Turkey. Contrib Mineral Petrol, 58: 63-81

Peng P, Zhai M G, Ernst R E, Guo J H, Liu F, Hu B. 2008. A 1.78 Ga large igneous province in the North China craton: The Xiong'er Volcanic Province and the North China dyke swarm. Lithos, 101: 260-280

Peng Z C, Zartman R E, Futa K, Chen D G. 1986. Pb-, Sr- and Nd-isotopic systematics and chemical characteristics of Cenozoic basalts, eastern China. Chem Geol-Isot Geosce Sec, 59: 3-33

Ren J Y, Tamaki K, Li S T, Zhang J X. 2002. Late Mesozoic and Cenozoic rifting and its dynamic setting in Eastern China and adjacent areas. Tectonophysics, 344: 175-205

Ritts B D, Darby B J, Cope T. 2001. Early Jurassic extensional basin formation in the Daqing Shan segment of the Yinshan belt, northern North China Block, Inner Mongolia. Tectonophysics, 339: 239-258

Roberts M P, Clemens J D. 1993. Origin of high-potassium, talc-alkaline, I-type granitoids. Geology, 21: 825-828

Sun S S, McDonough W F. 1989. Chemical and isotopic systematics of oceanic basalts: Implications for mantle composition and processes. Geol Soc Lond Spec Publ, 42: 313-345

Sylvester P J. 1998. Post-collisional strongly peraluminous granites. Lithos, 45: 29-44

Tang K F, Li J W, Selby D, Zhou M F, Bi S J, Deng X D. 2013. Geology, mineralization, and geochronology of the Qianhe gold deposit, Xiong'ershan area, southern North China Craton. Miner Depos, 48: $729-747$

Tang Y J, Zhang H F, Santosh M, Ying J F. 2013. Differential destruction of the North China Craton: A tectonic perspective. J Asian Earth Sci, 78: $71-82$

Tian Y, Zhao D P. 2011. Destruction mechanism of the North China Craton: Insight from $P$ and $S$ wave mantle tomography. J Asian Earth Sci, 42: 1132-1145

Van Staal C, De Roo J. 1995. Mid-Paleozoic tectonic evolution of the Appalachian Central Mobile Belt in northern New Brunswick, Canada:
Collision, extensional collapse and dextral transpression. In: Hibbard J P, van Staal C R, Cawood P A, eds. Current Perspectives in the Appalachian-Caledonian Orogen. Geol Assoc Can Spec Paper, 41: 367-389

Van Wagoner N A, Leybourne M I, Dadd K A, Baldwin D K, McNeil W. 2002. Late Silurian bimodal volcanism of southwestern New Brunswick, Canada: Products of continental extension. Geol Soc Am Bull, 114: 400-418

Waight T E, Weaver S D, Muir R J. 1998. Mid-Cretaceous granitic magmatism during the transition from subduction to extension in southern New Zealand: A chemical and tectonic synthesis. Lithos, 45: 469-482

Wan Y S, Wilde S A, Liu D Y, Yang C X, Song B, Yin X Y. 2006. Further evidence for $\sim 1.85 \mathrm{Ga}$ metamorphism in the Central Zone of the North China Craton: SHRIMP U-Pb dating of zircon from metamorphic rocks in the Lushan area, Henan Province. Gondwana Res, 9: 189-197

Wang C M, Chen L, Bagas L, Lu Y J, He X Y, Lai X R. 2015. Characterization and origin of the Taishanmiao aluminous A-type granites: Implications for Early Cretaceous lithospheric thinning at the southern margin of the North China Craton. Int J Earth Sci: 1-27

Wang L J, Griffin W L, Yu J H, O’Reilly S Y. 2013. U-Pb and Lu-Hf isotopes in detrital zircon from Neoproterozoic sedimentary rocks in the northern Yangtze Block: Implications for Precambrian crustal evolution. Gondwana Res, 23: 1261-1272

Wang Q, Wyman D A, Xu J F, Jian P, Zhao Z H, Li C F, Xu W, Ma J L, He B. 2007. Early Cretaceous adakitic granites in the Northern Dabie Complex, central China: Implications for partial melting and delamination of thickened lower crust. Geochim Cosmochim Acta, 71: 2609-2636

Wang X L, Jiang S Y, Dai B Z. 2010. Melting of enriched Archean subcontinental lithospheric mantle: Evidence from the ca. $1760 \mathrm{Ma}$ volcanic rocks of the Xiong'er Group, southern margin of the North China Craton. Precambrian Res, 182: 204-216

Wang X X, Wang T, Ke C H, Yang Y, Li J B, Li Y H, Qi Q J, Lv X Q. 2015. Nd-Hf isotopic mapping of Late Mesozoic granitoids in the East Qinling orogen, central China: Constraint on the basements of terranes and distribution of Mo mineralization. J Asian Earth Sci, 103: $169-183$

Wang Y J, Fan W M, Peng T P, Zhang H F, Guo F. 2005. Nature of the Mesozoic lithospheric mantle and tectonic decoupling beneath the Dabie Orogen, Central China: Evidence from ${ }^{40} \mathrm{Ar} /{ }^{39} \mathrm{Ar}$ geochronology, elemental and $\mathrm{Sr}-\mathrm{Nd}-\mathrm{Pb}$ isotopic compositions of early Cretaceous mafic igneous rocks. Chem Geol, 220: 165-189

Wang Y T, Mao J W, Lu X X, Ye A W. 2002. ${ }^{40} \mathrm{Ar}-{ }^{39} \mathrm{Ar}$ dating and geological implication of auriferous altered rocks from the middle- 
deep section of Q875 gold-quartz vein in Xiaoqinling area, Henan, China. Chin Sci Bull, 47: 1750-1755

Wu F Y, Lin J Q, Wilde S A, Zhang X, Yang J H. 2005. Nature and significance of the Early Cretaceous giant igneous event in eastern China. Earth Planet Sci Lett, 233: 103-119

Wu Y B, Zheng Y F. 2013. Tectonic evolution of a composite collision orogen: An overview on the Qinling-Tongbai-Hong'an-Dabie-Sulu orogenic belt in central China. Gondwana Res, 23: 1402-1428

Xie Z, Zheng Y F, Zhao Z F, Wu Y B, Wang Z R, Chen J F, Liu X M, Wu F Y. 2006. Mineral isotope evidence for the contemporaneous process of Mesozoic granite emplacement and gneiss metamorphism in the Dabie orogen. Chem Geol, 231: 214-235

Xu H J, Ma C Q, Ye K. 2007. Early cretaceous granitoids and their implications for the collapse of the Dabie orogen, eastern China: SHRIMP zircon U-Pb dating and geochemistry. Chem Geol, 240: 238-259

Xu W L, Gao S, Wang Q H, Wang D Y, Liu Y S. 2006. Mesozoic crustal thickening of the eastern North China craton: Evidence from eclogite xenoliths and petrologic implications. Geology, 34: 721

Xu X S, Griffin W L, Ma X, O'Reilly S Y, He Z Y, Zhang C L. 2009. The Taihua group on the southern margin of the North China craton: Further insights from $\mathrm{U}-\mathrm{Pb}$ ages and $\mathrm{Hf}$ isotope compositions of zircons. Miner Petrol, 97: 43-59

Xu Y G, Li H Y, Pang C J, He B. 2009. On the timing and duration of the destruction of the North China Craton. Chin Sci Bull, 54: 3379-3396

Xue F, Rowley D B, Tucker R D, Peng Z X. 1997. U-Pb zircon ages of granitoid rocks in the north Dabie complex, eastern Dabie Shan, China. J Geol, 105: 744-753

Yang J, Gao S, Yuan H L, Gong H J, Zhang H, Xie S W. 2007. Detrital Zircon ages of Hanjiang River: Constraints on evolution of northern Yangtze craton, South China. J China Uni Geosci, 18: 210-222

Yang J H, Chung S L, Wilde S A, Wu F, Chu M F, Lo C H, Fan H R. 2005. Petrogenesis of post-orogenic syenites in the Sulu Orogenic Belt, East China: Geochronological, geochemical and Nd-Sr isotopic evidence. Chem Geol, 214: 99-125

Yang J H, Wu F Y, Chung S L, Wilde S A, Chu M F. 2006. A hybrid origin for the Qianshan A-type granite, northeast China: Geochemical and Sr-Nd-Hf isotopic evidence. Lithos, 89: 89-106

Yang J H, Wu F Y, Wilde S A, Belousova E, Griffin W L. 2008a. Mesozoic decratonization of the North China block. Geology, 36: 467-470

Yang J H, Wu F Y, Wilde S A, Chen F, Liu X M, Xie L W. 2008b. Petrogenesis of an alkali syenite-granite-rhyolite suite in the Yanshan Fold and Thrust Belt, Eastern North China Craton: Geochronological, geochemical and $\mathrm{Nd}-\mathrm{Sr}-\mathrm{Hf}$ isotopic evidence for lithospheric thinning. $\mathrm{J}$ Petrol, 49: 315-351

Yang L, Chen F K, Liu B X, Hu Z P, Qi Y, Wu J D, He J F, Siebel W. 2013. Geochemistry and $\mathrm{Sr}-\mathrm{Nd}-\mathrm{Pb}-\mathrm{Hf}$ isotopic composition of the
Donggou Mo-bearing granite porphyry, Qinling orogenic belt, central China. Int Geol Rev, 55: 1261-1279

Yang Q Y, Santosh M, Shen J F, Li S R. 2014. Juvenile vs. recycled crust in NE China: Zircon U-Pb geochronology, Hf isotope and an integrated model for Mesozoic gold mineralization in the Jiaodong Peninsula. Gondwana Res, 25: 1445-1468

Yang W, Teng F Z, Zhang H F, Li S G. 2012. Magnesium isotopic systematics of continental basalts from the North China craton: Implications for tracing subducted carbonate in the mantle. Chem Geol, 328: 185-194

Yang Z F. 2012. Combining quantitative textural and geochemical studies to understand the solidification processes of a granite porphyry: Shanggusi, east Qinling, China. J Petrol, 53: 1807-1835

Yang Z F, Luo Z H, Lu X X, Huang F, Chen B H, Zhou J L, Cheng L L. 2014. The role of external fluid in the Shanggusi dynamic granitic magma system, East Qinling, China: Quantitative integration of textural and chemical data. Lithos, 208-209: 339-360

Zhai M, Santosh M. 2013. Metallogeny of the North China Craton: Link with secular changes in the evolving Earth. Gondwana Res, 24: 275-297

Zhang H F. 2012. Destruction of ancient lower crust through magma underplating beneath Jiaodong Peninsula, North China Craton: U-Pb and $\mathrm{Hf}$ isotopic evidence from granulite xenoliths. Gondwana Res, 21: $281-292$

Zhang H F, Gao S, Zhong Z Q, Zhang B R, Zhang L, Hu S H. 2002. Geochemical and $\mathrm{Sr}-\mathrm{Nd}-\mathrm{Pb}$ isotopic compositions of Cretaceous granitoids: Constraints on tectonic framework and crustal structure of the Dabieshan ultrahigh-pressure metamorphic belt, China. Chem Geol, 186: 281-299

Zhang H F, Zhu R X, Santosh M, Ying J F, Su B X, Hu Y. 2013. Episodic widespread magma underplating beneath the North China Craton in the Phanerozoic: Implications for craton destruction. Gondwana Res, 23: $95-107$

Zhang J J, Zheng Y D. 1999. Multistage extension and age dating of the Xiaoqinling metamorphic core complex, central China. Acta Geol Sin-Engl Ed, 73: 139-147

Zhao D P, Maruyama S, Omori S. 2007. Mantle dynamics of Western Pacific and East Asia: Insight from seismic tomography and mineral physics. Gondwana Res, 11: 120-131

Zhao G C, Wilde S A, Cawood P A, Sun M. 2001. Archean blocks and their boundaries in the North China Craton: Lithological, geochemical, structural and P-T path constraints and tectonic evolution. Precambrian Res, 107: 45-73

Zhao H X, Jiang S Y, Frimmel H E, Dai B Z, Ma L. 2012. Geochemistry, geochronology and Sr-Nd-Hf isotopes of two Mesozoic granitoids in the Xiaoqinling gold district: Implication for large-scale lithospheric 
thinning in the North China Craton. Chem Geol, 294-295: 173-189

Zhao T P, Zhai M G, Xia B, Li H M, Zhang Y X, Wan Y S. 2004. Study on the zircon SHRIMP ages of the Xiong'er Group volcanic rocks: Constraint on the starting time of covering strata in the North China Craton. Chin Sci Bull, 9: 2495-2502

Zhao Z F, Zheng Y F, Wei C S, Wu Y B. 2004. Zircon isotope evidence for recycling of subducted continental crust in post-collisional granitoids from the Dabie terrane in China. Geophys Res Lett, 31: L22602

Zhao Z F, Zheng Y F, Wei C S, Wu Y B. 2007. Post-collisional granitoids from the Dabie orogen in China: Zircon $\mathrm{U}-\mathrm{Pb}$ age, element and $\mathrm{O}$ isotope evidence for recycling of subducted continental crust. Lithos,
93: $248-272$

Zhu G, Jiang D, Zhang B, Chen Y. 2012. Destruction of the eastern North China Craton in a backarc setting: Evidence from crustal deformation kinematics. Gondwana Res, 22: 86-103

Zhu G, Niu M L, Xie C L, Wang Y S. 2010. Sinistral to normal faulting along the Tan-Lu Fault Zone: Evidence for geodynamic switching of the east China continental margin. J Geol, 118: 277-293

Zhu X Y, Chen F, Liu B X, Siebel W. 2013. Zircon U-Pb and K-feldspar megacryst $\mathrm{Rb}-\mathrm{Sr}$ isotopic ages and $\mathrm{Sr}-\mathrm{Hf}$ isotopic composition of the Mesozoic Heyu pluton, eastern Qingling orogen, China. Lithos, 156-159: $31-40$ 